Published in final edited form as:

J Med Chem. 2016 August 25; 59(16): 7431-7444. doi:10.1021/acs.jmedchem.6b00160.

\title{
Discovery of (R)-2-(6-Methoxynaphthalen-2-yl)butanoic Acid as a Potent and Selective Aldo-keto Reductase 1C3 Inhibitor
}

\author{
Adegoke Adeniji ${ }^{\dagger} \S$, Md. Jashim Uddin ${ }^{\ddagger}$, Tianzhu Zang ${ }^{\dagger}$, Daniel Tamae ${ }^{\dagger}$, Phumvadee \\ Wangtrakuldee $^{\dagger}$, Lawrence J. Marnett ${ }^{\ddagger}$, and Trevor M. Penning ${ }^{\dagger}{ }^{*}$ \\ tDepartment of Systems Pharmacology and Translational Therapeutics and the Center for \\ Excellence in Environmental Toxicology, Perelman School of Medicine, University of \\ Pennsylvania, 1315 BRBII/III, 421 Curie Boulevard, Philadelphia, Pennsylvania 19104-6160, \\ United States \\ FDepartments of Biochemistry, Chemistry, and Pharmacology, Vanderbilt Institute of Chemical \\ Biology, Center in Molecular Toxicology, Vanderbilt-Ingram Cancer Center, Vanderbilt University \\ School of Medicine, Nashville, Tennessee 37232-0146, United States
}

\section{Abstract \\ Type 5 17ß-hydroxysteroid dehydrogenase, aldo-keto reductase 1C3 (AKR1C3) converts $\Delta^{4}$ - androstene-3,17-dione and 5a-androstane-3,17-dione to testosterone (T) and 5a- dihydrotestosterone, respectively, in castration resistant prostate cancer (CRPC). In CRPC, AKR1C3 is implicated in drug resistance, and enzalutamide drug resistance can be surmounted by indomethacin a potent inhibitor of AKR1C3. We examined a series of naproxen analogues and find that $(R)$-2-(6-methoxynaphthalen-2-yl)butanoic acid (in which the methyl group of $R$ - naproxen was replaced by an ethyl group) acts as a potent AKR1C3 inhibitor that displays}

\footnotetext{
*Corresponding Author. Phone: 215-898-9445. Fax: 215-573-2236. penning @ upenn.edu. §Present Address

Dr. Adegoke Adeniji, Department of Pharmaceutical Sciences, South University School of Pharmacy, 709 Mall Boulevard, Savannah, Georgia 31406, United States

ASSOCIATED CONTENT

Supporting Information

The Supporting Information is available free of charge on the ACS Publications website at DOI: 10.1021/acs.jmedchem.6b00160.
}

\author{
Molecular formula strings (CSV) \\ Molecular model of AKR1C3.NADP $+.14 a(P D B)$ \\ Molecular model of AKR1C3.NADP ${ }^{+} .14 b(P D B)$ \\ Molecular model of AKR1C2.NADP ${ }^{+} .14 a(P D B)$ \\ Molecular model of AKR1C2.NADP $+.14 b(P D B)$
}

SDS-PAGE of homogeneous enzymes, and chiral separation of compounds 9a, 9b, 14a, and 14b (PDF)

Author Contributions

Dr. Adegoke Adeniji wrote the first draft of the manuscript and performed the initial screening experiments. Dr. Md. Jashim Uddin synthesized the naproxen analogues. Dr. Indy Zang conducted additional screening experiments and chiral separation of enantiomers. Dr. Daniel Tamae performed the cell-based assays, and Dr. Phumvadee Wangtrakuldee performed the molecular modeling studies. Compounds were supplied or synthesized in the laboratory of Dr. Larry J. Marnett. Dr. Marnett edited drafts of the manuscript. Dr. Trevor Penning conceived of the study, directed all the work, and edited the final manuscript.

The authors declare the following competing financial interest(s): Dr. Trevor Penning is founder of Penzymes LLC and both Drs. Penning and Marnett have an equity share in this LLC. 
selectivity for AKR1C3 over other AKR1C enzymes. This compound was devoid of inhibitory activity on COX isozymes and blocked AKR1C3 mediated production of T and induction of PSA in LNCaP-AKR1C3 cells as a model of a CRPC cell line. $R$-Profens are substrate selective COX-2 inhibitors and block the oxygenation of endocannabinoids and in the context of advanced prostate cancer $R$-profens could inhibit intratumoral androgen synthesis and act as analgesics for metastatic disease.

\section{Graphical Abstract}

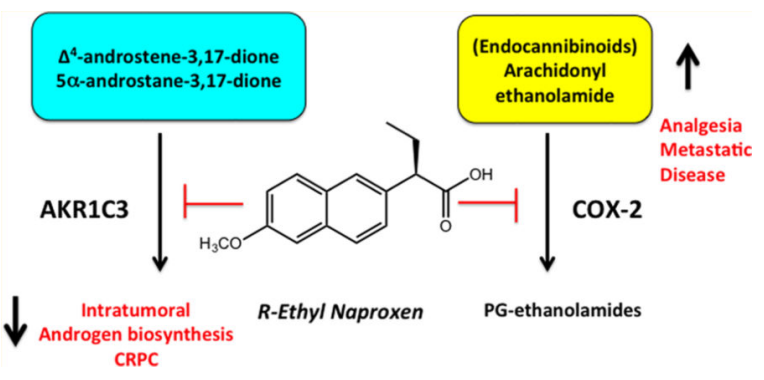

\section{INTRODUCTION}

The development of castrate resistant prostate cancer (CRPC) in patients that have undergone androgen deprivation therapy (ADT) is driven by reactivation of androgen receptor (AR) signaling within the tumor in the presence of castrate levels of circulating androgens. ${ }^{1,2}$ AR reactivation results from adaptive intratumoral androgen biosynthesis ${ }^{3-5}$ and from changes in the AR itself, including gene amplification, ${ }^{6} \mathrm{AR}$ mutations that make the receptor ligand permissive, ${ }^{7,8}$ and the appearance of AR splice variants ${ }^{9,10}$ which make the receptor constitutively active.

The importance of the conversion of adrenal androgens into testosterone (T) and 5adihydrotestosterone (5a-DHT) or de novo androgen biosynthesis within the tumor is firmly established by the therapeutic efficacy of abiraterone acetate (AA), an inhibitor of P450c17 (17a-hydroxylase/17,20 lyase) in CRPC patients. ${ }^{11-15}$ However, concerns over the need for coadministration of prednisone with AA to prevent adrenal insufficiency and the rapid appearance of drug resistance indicate a pressing need for new therapeutic agents. ${ }^{16,17}$

Aldo-keto reductase 1C3 (AKR1C3), also known as type 5 17ß-hydroxysteroid dehydrogenase (HSD17B5), is a 17-ketoreductase that catalyzes the NADPH dependent conversion of androgen precursors, 4 -androstene-3,17-dione $\left(\Delta^{4}-\mathrm{AD}\right)$ and $5 \mathrm{a}$ androstan-3,17-dione (5-Adione), to yield the potent androgens, T and 5a-DHT, respectively (Scheme 1). ${ }^{18,19}$ AKR1C3 also catalyzes the conversion of androsterone to $5 a-$ androstane-3a,17 $\beta$-diol, the precursor of $5 a-D H T$ in the backdoor pathway. ${ }^{20,21}$ AKR1C3 is one of the most highly overexpressed steroidogenic enzymes in CRPC compared to normal prostate tissue and prostate cancer. ${ }^{22-26}$ Moreover, it is dramatically upregulated by ADT. ${ }^{23,27,28}$ Upon ADT, AKR1C3 is induced by the TMPRSS2-ERG fusion protein, whereby the ERG transcription factor can override the repressive effects of the AR binding to the AKR1C3 promoter. ${ }^{29} \mathrm{AKR} 1 \mathrm{C} 3$ also plays a role in resistance to $\mathrm{P} 450 \mathrm{c} 17$ inhibition 
by AA observed in prostate cancer cell lines and xenografts. ${ }^{16,17}$ AKR1C3 may also act as an AR selective coactivator that promotes tumor growth, and this coactivator function could be blocked with small molecule enzyme competitive inhibitors. ${ }^{30}$

Enzalutamide (ENZ) is an AR superantagonist which is also used to treat CRPC patients, ${ }^{31-33}$ and drug resistance also occurs with this agent. ENZ drug resistance in cell lines and in xenografts could be surmounted with indomethacin, a non-steroidal antiinflammatory drug (NSAID) and competitive inhibitor of AKR1C3 identified in this laboratory. ${ }^{34,35}$ We are repurposing NSAIDs to be devoid of COX-1 or COX-2 inhibition while maintaining their inhibitory potency for AKR1C3. We have previously reported on indomethacin and fenamate analogues that have the requisite nanomolar inhibitory potency and selectivity for AKR1C3. ${ }^{36,37}$ These agents do not inhibit COX isozymes, nor do they inhibit AKR1C1 and AKR1C2, which are required for the inactivation of 5a-DHT within the prostate. ${ }^{38-40}$

Naproxen, (S)-2-(6-methoxynaphthalen-2-yl)propanoic acid is a NSAID that is used clinically to block cyclooxygenase (COX) mediated inflammation. It is also a potent AKR1C3 inhibitor that inhibits the AKR1C3 catalyzed reduction of the bioreductive drug PR-104 in multiple human cancer cells lines and a lung cancer xenograft model. ${ }^{41}$ However, naproxen also inhibits AKR1C2, ${ }^{34}$ which limits its therapeutic potential in CRPC.

We set out to develop naproxen-based AKR1C3 inhibitors that would be useful in CRPC but are devoid of inhibitory activity on COX and other AKR1C enzymes. We report the discovery of (R)-2-(6-methoxynaphthalen-2-yl)butanoic acid as a competitive, potent, and selective AKR1C3 inhibitor which identifies $R$-profens as a new class of repurposed NSAIDs for CRPC patients. $R$-Profens are also substrate selective inhibitors of COX-2 oxygenation of endocannabinoids, raising the prospect that in the context of prostate cancer they may prevent intratumoral androgen biosynthesis and act as analgesics in metastatic disease. ${ }^{42,43}$

\section{RESULTS}

\section{Chemistry}

$S$-Naproxen 1 was the precursor of compounds 5, 6, and 9-11 (Schemes 2 and 3). A common intermediate was $S$-methyl-2-(6-trifluoromethylsulfonyloxynaphthalene propanoate, 4. This compound was synthesized from $S$-naproxen, which was converted to $O$ demethyl naproxen $\mathbf{2}$ under acidic conditions followed by esterification to yield $\mathbf{3} .{ }^{42}$ Subsequent addition of trifluoromethane sulfonic anhydride in base gave $\mathbf{4}$. Compound 4 was converted to compound 5 via the 6-vinylogous intermediate and deesterification. The protected acid $\mathbf{3}$ was converted to the ethoxy intermediate using iodoethane and desesterification and gave compound $\mathbf{6}$ (Scheme 2). Coupling of $\mathbf{4}$ with sodium triisopropylsilanethiolate followed by deprotection with tetrabutylammonium fluoride gave (S)-2-(6-(methylthio)naphthalen-2-yl)propanoate 8, which upon base hydrolysis yielded the racemic acid, 9. The racemic acid was further oxidized with $m$-chloroperoxybenzoic acid to yield racemic 2-(6-methylsulfinyl)naphthalene-2-yl)-propanoic acid 10, Scheme 3. The steps to compound $\mathbf{1 1}$ are identical except the final oxidation of the methyl-thio derivative to yield 
the methylsufonyl derivative used potassium peroxymonosulfate (Oxone), Scheme 3.

Compound 14 was synthesized in two steps from 2-bromo-6-methoxy-naphthalene 12. ${ }^{42}$ Compound 15 was synthesized from racemic 14 via $1,1^{\prime}$-carbonyldiimidazole coupling of methanesulfonamide, Scheme 3.

AKR1C3 and AKR1C2 Inhibitor Screening-Naproxen analogues were synthesized to explore the effect of modifications of its structure on AKR1C3 activity and selectivity. On the basis of the observation that other NSAIDs require the carboxylic acid group for optimal inhibition of the AKR1C enzymes, ${ }^{44}$ most of the synthesized compounds retained this functional group. Modifications were made primarily on the chiral a-carbon or the 6position of the naphthalene ring. Because of the presence of the chiral center in the molecule, most of compounds were initially assayed as racemates and screened for AKR1C2 and AKR1C3 inhibition without separation of the enantiomers.

The ability of the compounds to inhibit the $\mathrm{NADP}^{+}$dependent oxidation of $S$-tetralol catalyzed by AKR1C 3 and AKR1C2 was determined and $\mathrm{IC}_{50}$ values obtained, Figure 1 and Table 1. Because the $S$-tetralol assays were performed at $K_{\mathrm{m}}$, the $\mathrm{IC}_{50}$ values for the two enzymes were directly comparable. Naproxen inhibited AKR1C3 with an $\mathrm{IC}_{50}$ value of 180 $\mathrm{nM}$ and was not selective for AKR1C3 over AKR1C2, consistent with previous studies. ${ }^{45}$ As naproxen, $\mathbf{1}$ is an $S$-enantiomer, its $R$-enantiomer, 1a, was evaluated for AKR1C3 inhibition and selectivity. $R$-Naproxen inhibited AKR1C3 and AKR1C2 with $\mathrm{IC}_{50}$ values of $50 \mathrm{nM}$ and $2.75 \mu \mathrm{M}$, respectively, which makes it more potent and more selective for AKR1C3 than naproxen. Replacement of the 6-OMe group of naproxen with an -Et to give 5 or an -OEt to give $\mathbf{6}$ did not change the potency and selectivity for AKR1C3. On the other hand, an isosteric replacement of the 6-OMe with the thiomethyl group, $-\mathrm{SMe}$, to give compound 9, led to a 3-fold increase in the inhibitory potency for AKR1C3 $\left(\mathrm{IC}_{50}=60 \mathrm{nM}\right)$ over that seen with naproxen while the AKR1C2 inhibitory potency remained unchanged. This translated to 25-fold selectivity for AKR1C3 over AKR1C2 by compound 9 . Because the $-\mathrm{SMe}$ group can be metabolized to the $\mathrm{S}(=\mathrm{O}) \mathrm{Me}$ and $\mathrm{S}(=\mathrm{O})_{2} \mathrm{Me}$ groups, compounds 10 and $\mathbf{1 1}$ containing these functional groups at the 6-position were synthesized and screened for AKR1C3 activity and selectivity. Compared to $\mathbf{9}$, both compounds $\mathbf{1 0}$ and $\mathbf{1 1}$ displayed a greater than 15 -fold loss of inhibitory potency on AKR1C3.

The $N$-(methylsulfonyl)acetamide analogue, 15, displayed a significant loss of inhibitory activity for AKR1C3 and AKR1C2, with $\mathrm{IC}_{50}$ values of 6.0 and $34 \mu \mathrm{M}$, respectively, underscoring the need for a free carboxylic acid group for optimal inhibition of the AKR1C enzymes. Next, the replacement of the a-Me group of naproxen with an -Et gave 14, which was the most AKR1C3 selective racemate evaluated. With an $\mathrm{IC}_{50}$ value of $120 \mathrm{nM}$ against AKR1C3, compound $\mathbf{1 4}$ was more potent as an AKR1C3 inhibitor than naproxen and was 58 -fold selective for AKR1C3 over AKR1C2. Because of its favorable properties, the racemic mixture of 14 was separated to give the $R$ - (14a) and the $S$ - (14b) enantiomers. The configuration of the enantiomers was inferred by comparing the elution order of the enantiomers with that of naproxen and $R$-naproxen when the same chiral column and mobile phase was used (see Supporting Information). Surprisingly, while the AKR1C3 inhibitory potency of the enantiomers was similar and not significantly different from the inhibitory 
potency of the racemate, the AKR1C2 inhibitory potency of the enantiomers was markedly different. The $S$-enantiomer inhibited AKR1C2 with an $\mathrm{IC}_{50}$ of $1.72 \mu \mathrm{M}$, while the $R$ enantiomer displayed an $\mathrm{IC}_{50}$ value of $46.4 \mu \mathrm{M}$ against AKR1C2. This translated to 14- and 437-fold selectivity for AKR1C3 inhibition over AKR1C2, respectively. Eliminating the chiral center of naproxen by the removal of the a-Me group to give $\mathbf{1 6}$ led to a loss of inhibitory potency and selectivity for AKR1C3, indicating the importance in retaining the $R$ configuration. The $R$ - and $S$ - enantiomers of compound 9 were also examined based on the selectivity achieved with the $R$-enantiomer 14a. Compound 9a showed 87 -fold selectivity for AKR1C3, which was 5-fold less than the selectivity observed with compound 14a, demonstrating that the -OMe was preferred over the more bulky $-\mathrm{SMe}$.

Compound 14a was the most selective AKR1C3 inhibitor identified from the primary screen. When tested for inhibition of AKR1C1, it displayed selectivity for AKR1C3 over $\mathrm{AKR} 1 \mathrm{C} 1$ inhibiting the latter with an $\mathrm{IC}_{50}$ value of $50 \mu \mathrm{M}$, which translates to a 500 -fold selectivity for AKR1C3 (Figure 2.) Similarly, selectivity was observed when the compound was screened against AKR1C4.

Effect of 14a on AKR1C2 Catalyzed Reduction of 5a-DHT-Compounds 14a and 14b were next evaluated for the ability to inhibit AKR1C2 catalyzed NADPH dependent reduction of 5a-DHT. This was necessary to establish the lack of inhibitory activity on AKR1C2 using its physiologically relevant ketosteroid substrate. In this reaction, compound 14b inhibited AKR1C2 in a dose-dependent manner over the concentration range of 3-100 $\mu \mathrm{M}$, achieving $70 \%$ inhibition of enzyme activity at $100 \mu \mathrm{M}$ (Figure 3). In contrast, 14a did not display any significant inhibition of $\mathrm{AKR} 1 \mathrm{C} 2$ at $<100 \mu \mathrm{M}$ concentrations. Flufenamic acid (FLU), a nonselective inhibitor of the AKR1C enzymes, displayed about $70 \%$ inhibition of AKR1C2 at $10 \mu \mathrm{M}$ concentration.

Mode of AKR1C3 Inhibition by $14 a-T h e$ pattern of AKR1C3 inhibition by $14 a$ was evaluated in by measuring the $\mathrm{NADP}^{+}$dependent oxidation of $S$-tetralol and by measuring the NADPH dependent reduction of $\Delta^{4}$-androsten-3,17-dione. Compound 14a competitively inhibited the AKR1C3 catalyzed oxidation of $S$-tetralol, with a $K_{\mathrm{i}}$ value of $31 \mathrm{nM}$ (Figure 4a). The same mode of inhibition was also observed when the reduction of $\Delta^{4}$-AD was monitored, albeit with a much higher $K_{\mathrm{i}}$ value of $750 \mathrm{nM}$ (Figure $4 \mathrm{~b}$ ).

Inhibition of COX-1-Naproxen inhibited COX-1 with an $\mathrm{IC}_{50}$ value of $61 \mathrm{nM}$. Relative to naproxen, $\mathbf{1 4 b}$ displayed a 30 -fold loss of inhibitory potency on COX-1, with an $\mathrm{IC}_{50}$ value of $1.93 \mu \mathrm{M}$ (Figure 5). There was a profound loss of inhibitory activity on COX-1 activity by the respective $R$-enantiomers, compounds 1 a and 14a. Both compounds displayed less than $20 \%$ inhibition of COX-1 activity at the highest inhibitor concentration $(100 \mu \mathrm{M})$ tested. This is consistent with reported structure-activity relationship studies on the COX-1 inhibitory effects of naproxen and its analogues.

A comparison of inhibitory potency of the compounds against AKR1C3 and COX-1 (Table 2) shows that 14a was almost a thousandfold more selective for AKR1C3 over COX-1.

Compound $\mathbf{1 4}$, which is a racemate of $\mathbf{1 4} \mathbf{a}$ and $\mathbf{1 4 b}$, had no inhibitory activity on COX-2 at the maximum concentration of arachidonic acid tested as substrate $(10 \mu \mathrm{M})$. 


\section{Effect on AR Reporter Gene Assay}

Compound 14a was next evaluated for a direct effect on AR signaling. Compound 14a did not effect the trans-activation of the AR mediated by 5a-DHT. There was a concentrationdependent increase in luciferase activity when HeLa1 3 cells containing a stably transfected $\mathrm{AR}$ and an androgen response element driven luciferase gene were treated with increasing concentrations of 5a-DHT. The luciferase activity peaked at $0.3 \mathrm{nM} 5 \mathrm{a}-\mathrm{DHT}$, however, there were no significant change in the 5a-DHT induced luciferase expression when cells were treated with increasing concentrations of $5 \mathrm{a}$-DHT in the presence of $10 \mu \mathrm{M}$ compound 14a, Figure 6.

\section{Inhibition of AKR1C3-Mediated Production of Testosterone}

LNCaP-AKR1C 3 cells were used to probe the metabolism of $\Delta^{4}-\mathrm{AD}$ in the presence and absence of compound 14a. Radio-labeled $\left[{ }^{3} \mathrm{H}\right]-\Delta^{4}$-AD was incubated with carrier $\Delta^{4}$-AD $(100 \mathrm{nM})$ with LNCaP-AKR1C3 cells placed in medium supplemented with charcoal dextran stripped fetal bovine serum (CD-FBS) which is devoid of androgens. Androgens were extracted after $48 \mathrm{~h}$ and the aqueous fraction subject to $\beta$-glucuronidase treatment to liberate androgen conjugates that we have previously shown to exist due to the robust uridine- $5^{\prime}$-diphospho-glucuronosyltransferse (UGT) activity in these cells. Metabolites were separated by radiochromatography using TLC. LNCaP-AKR1C3 cells were able to metabolize $\left[{ }^{3} \mathrm{H}\right]-\Delta^{4}-\mathrm{AD}$ to $\left[{ }^{3} \mathrm{H}\right]$-androsterone glucuronide and $\left[{ }^{3} \mathrm{H}\right]$-testosterone glucuronide. However, in cells that were treated with $30 \mu \mathrm{M}$ of compound 14a, the production of $\left[{ }^{3} \mathrm{H}\right]$-testosterone glucuronide was significantly inhibited (Figure 7).

\section{Inhibition of AKR1C3-Mediated AR Gene Expression}

Compound 14a was also tested for its ability to block the $\Delta^{4}$-AD mediated expression of PSA in LNCaP-AKR1C3 cells by Western blot analysis Figure 8. Treatment of these cells with $100 \mathrm{nM} \Delta^{4}$-AD led to a robust increase in PSA expression. This increase in PSA was reduced when the cells were treated with $100 \mathrm{nM} \Delta^{4}$-AD in the presence of $30 \mu \mathrm{M}$ of compound 14a.

\section{DISCUSSION}

CRPC is currently treated with either AA or ENZ, however, patients rapidly develop drug resistance leading to an increase in median survival time of only 3-4 months. One mechanism of drug resistance is overexpression of AKR1C3. AKR1C3 represents a rational target due to its vital role as "gatekeeper" for the production of potent androgens regardless of the pathway used and its ability to function as a coactivator for the AR. This underscores the intense attention the search for AKR1C3 inhibitors has generated. ${ }^{30,36,37,46-53}$

NSAIDs are known to be pan inhibitors of the AKR1C enzymes. This is thought to be as a result of the interaction of the carboxylate groups of NSAIDs with the catalytic site of the AKR1C enzymes. ${ }^{53}$ The inhibition of AKR1C3 by NSAIDs is attained at therapeutic concentrations that are required for COX inhibition. This makes using these compounds as leads a promising approach because the resulting analogues may have similar pharmacokinetic profiles and therefore may be well tolerated. We have conducted structure- 
activity relationship studies on the NSAID naproxen and identified a $R$-enantiomer that differs from $R$-naproxen by the simple substitution of an ethyl group for a methyl group with therapeutic potential for CRPC.

The presence of small lipophilic groups at the 6-position of naproxen is optimal for COX inhibitory activity. ${ }^{54,55}$ To determine the contribution of the 6-OMe group to the inhibitory potency of naproxen for AKR1C3, analogues with small substituents were synthesized and evaluated. With the exception of the 6-SMe, all the other substituents at the 6-position did not significantly improve AKR1C3 potency or selectivity.

All the compounds evaluated were superior inhibitors of AKR1C3 than AKR1C2. Because the AKR1C enzymes differ primarily in the enzyme subpockets, it is likely that the larger and more flexible subpockets of AKR1C 3 allow for better interaction with the enzyme. ${ }^{44,56}$

Naproxen, with a chiral center at the a-carbon, is used as the $S$-enantiomer for antiinflammatory activity. This is due to the $R$-enantiomer being significantly less active as a COX inhibitor, Figure 5. ${ }^{42,54}$ Naproxen is likewise a potent AKR1C3 inhibitor. However, $R$ naproxen, compound 1a, has never been evaluated for AKR1C3 inhibitory activity. Relative to naproxen, compound 1a was found to be more potent as an AKR1C3 inhibitor and less potent as an AKR1C2 inhibitor, which translated into an increased selectivity for AKR1C3 relative to AKR1C2. The higher affinity of 1a over naproxen for AKR1C3 is supported by crystallographic studies conducted by Flanagan et al. ${ }^{48}$ These authors reported that while both $S$ - and $R$-naproxen bind to AKR1C3 when the respective enantiomers were soaked separately into preformed crystals of the AKR1C3. NADP ${ }^{+}$complex, only the $R$ enantiomer was bound in the these crystals when cosoaked with both enantiomers. This observation was attributed to the number of intermolecular interactions made by the enantiomers with the enzyme despite having relatively similar binding poses with AKR1C3. Relative to naproxen, $R$-naproxen made more contacts with side chains in the active site and cofactor, leading to a greater complementarity. ${ }^{48}$ This would suggest the existence of stereochemical specificity in the interaction of $R$-profens with AKR1C 3 and loss of specificity with AKR1C2. To further explore this observation, compound $\mathbf{1 4}$ with an a-Et group and its respective enantiomers $(R)$-14a and $(S)$-14b were subsequently evaluated. Surprisingly, the expected stereochemical specificity was not apparent in the interaction of the enantiomers 14a and 14b with AKR1C3 but was observed with AKR1C2 as the two enantiomers displayed markedly different inhibitory potency toward AKR1C2. The different inhibitory potency of the enantiomers on AKR1C2 was subsequently confirmed using a steroidal substrate for AKR1C2. Modeling studies of enantiomers 14a and 14b indicate that they adopt remarkably distinct binding poses with AKR1C2 (see Figures 9 and 10).

Ligand alignments of enantiomers 14a and 14b to the existing crystal structures (3UFY and 3R58) indicate that they adopt similar binding poses with AKR1C3 (Figure 9). Both analogues 14a and $14 \mathbf{b}$ show a similar binding mode to that of $R$-naproxen with the ethyl group occupying the subpocket 3 (SP3) formed by residues Tyr-24, Glu-192, Ser-217, Ser-221, and Gln-222. ${ }^{47}$ The remainder of the molecule extends into the subpocket 1 (SP1) pocket composed of Ser-118, Asn-167, Phe-306, Phe-311, and Tyr-319. The ligand alignments revealed closer proximity of carboxylic group of $\mathbf{1 4 a}$ compared to $\mathbf{1 4 b}$ at the 
oxyanion site (Tyr-55, His-117, and the $\mathrm{NADP}^{+}$cofactor). A slight increase in inhibitory potency and selectivity of $\mathbf{1 4 a}$ may be due to the favorable $\mathrm{H}$-bond interaction with the oxyanion site.

Compounds 14a and 14b display remarkably different binding poses to each other with AKR1C2 (Figure 10). While analogue 14a binds in the active site of AKR1C2 similarly to AKR1C3, compound 14b further extends into the SP3 pocket with no interaction with the SP1 pocket. When the structures of AKR1C2 and AKR1C3 with either 14a or 14b bound were overlaid, additional reasons for the AKR1C3 selectivity of compound $\mathbf{1 4 a}$ were found. The Leu 308 side chain at the AKR1C2 binding site sterically clashes with 14a, which may significantly decrease its preference toward binding in the SP1 pocket of AKR1C2, resulting in a loss of inhibitory potency for AKR1C2.

Compound 14a competes with $S$-tetralol and the physiologically relevant steroidal substrate, $\Delta^{4}$-AD, for binding to AKR1C3, albeit with different binding constants. The difference in binding constant is related to the formation of two different inhibitor complexes. ${ }^{34}$ During the competitive inhibition of $S$-tetralol, oxidation the E-NADP ${ }^{+}$.I complex forms (where I = inhibitor) to yield a $K_{\mathrm{i}}=31 \mathrm{nM}$ for 14a. By contrast, during the competitive inhibition of $\Delta^{4}$-AD reduction, the E-NADPH.I complex forms to yield a $K_{\mathrm{i}}=750 \mathrm{nM}$ for $\mathbf{1 4 a}$. Thus, compound 14a displays a 20 -fold preference for the E.NADP ${ }^{+}$complex, Figure 11 . Which complex is inhibited in cells is unclear.

Indomethacin, another NSAID, has been shown to have greater affinity for the E·NADP ${ }^{+}$ complex, presumably due to the interaction between the negative charge on the compound and the positive charge of $\mathrm{NADP}^{+} .{ }^{44}$ Because most AKR1C 3 inhibitors that have a carboxylic acid group are anchored to the enzyme's catalytic site via this functional group, ${ }^{37,47,48,56,57}$ compound 14a with a negatively charged carboxylic acid group at $\mathrm{pH} 7$ will likewise be expected to have similar interaction. This would bring the negative charge of 14a close to the cofactor where it will form a stronger interaction with $\mathrm{NADP}^{+}$relative to NADPH. The stronger interaction between 14a and NADP ${ }^{+}$would account for the lower $K_{\mathrm{i}}$ value obtained for 14a during the oxidation of $S$-tetralol by AKR1C3 when compared to the value obtained during the reduction of $\Delta^{4}$-AD by AKR1C3.

Compound 14a, had no effect on the transactivation of the AR mediated by 5a-DHT in HeLa cells. These cells were also shown to express AKR1C3 endogenously (Adeniji and Penning, unpublished). Thus, if AKR1C3 acts as an AR coactivator in these cells, then compound 14a differs from GTx560 in that it does not block coactivator function. ${ }^{30}$ This would suggest that not all competitive inhibitors of AKR1C3 are able to inhibit the coactivator function of this protein. However, coactivator function and its inhibition can be cell context dependent.

Consistent with the stereoselective inhibition of COX observed with naproxen, compound 14a was likewise devoid of inhibitory activity on COX, which is essential because chronic COX inhibition is not desirable in the context of CRPC management. We anticipate that due to the close structural similarity of naproxen with compound 14a, where the methyl group of $R$-naproxen was simply replaced by an ethyl group in compound $14 a$, that compound $14 \mathbf{b}$ 
would have favorable absorption, distribution, metabolism, elimination, and toxicological (ADMET) properties that would enable its rapid transit into man. However, it is recognized that the addition of the extra methylene group may effect the compounds' lipohilicity and hence affect these properties.

We also note with interest that $(R)$-profens are substrate-selective inhibitors of endocannabinoid oxygenation by COX-2 and suggest that they will have analgesic benefit by this mechanism. ${ }^{42,43}$ As a consequence, $(R)$-profens in CRPC may not only inhibit intratumoral androgen synthesis but may alleviate pain associated with the metastatic disease.

\section{CONCLUSION}

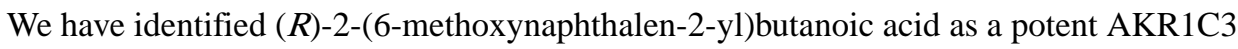
inhibitor. This compound competitively inhibits AKR1C3 and displays selectivity for AKR1C3 over other AKR1C enzymes and COX. It was also efficacious at blocking AKR1C3 in LNCaP-AKR1C3 cells, which is a model for CRPC cells. This compound represents a potential therapeutic agent that can be used in the management of CRPC either alone or in combination with AA or ENZ, where it may improve efficacy and reduce the incidence of resistance to these drugs.

\section{EXPERIMENTAL SECTION}

\section{Chemistry}

General: All commercially available reagents and anhydrous solvents were ACS grade or better and were used as received.

Analytical thin-layer chromatography was carried out using glassbacked plates coated with fluorescent silica gel 60 F254 from Whatman (Partisil LK6D). Spots were visualized under natural light and UV illumination at $\lambda=254$ and $365 \mathrm{~nm}$. Flash chromatography was conducted on a Biotage SP1 automated flash chromatography system equipped with a fixed wavelength UV detector $(\lambda=254 \mathrm{~nm})$. Samples were preabsorbed onto ready-made silica gel samplets and then applied on to normal-phase flash chromatography cartridges (Biotage KP-SIL, size according to requirements) and elution with a 0-100\% EtOAc/hexane (0.5\% acetic acid) gradient. ${ }^{1} \mathrm{H}$ and ${ }^{13} \mathrm{C}$ NMR spectra were recorded at 400 and $100 \mathrm{MHz}$, respectively, using a Bruker AV-400 with sample changer (BACS 60). A purity of $\geq 95 \%$ (unless otherwise indicated) for the final compounds in this study was confirmed by analytical HPLC on a Waters HPLC system with PDA detector (set at $\lambda=254 \mathrm{~nm}$ ) equipped with a Supelco Supelcosil LC-18 reverse-phase column ( $15 \mathrm{~cm} \AA \sim 3 \mathrm{~mm}, 5 \mu \mathrm{m})$. Compounds screened in the current study also were characterized with respect to their $\mathrm{mp}$ and HRMS.

\section{Preparation of Compounds}

(S)-Methyl 2-(6-(trifluoromethylsulfonyloxy)naphthalen-2-yl)propanoate, 4-To $(S)$-naproxen $(1,3 \mathrm{~g}, 13 \mathrm{mmol})$ in acetic acid $(20 \mathrm{~mL})$ was added $48 \% \mathrm{HBr}(11.2 \mathrm{~g}, 7.5 \mathrm{~mL}$, $138 \mathrm{mmol})$ at $0{ }^{\circ} \mathrm{C} .{ }^{57}$ Following $3 \mathrm{~h}$ of reflux, water $(40 \mathrm{~mL})$ was added to precipitate out 
the product $\mathbf{2}$, which was isolated by filtration. To the crude product $\mathbf{2}$ was added methanol $(35 \mathrm{~mL})$ and $\mathrm{TMSCl}(1.7 \mathrm{~g}, 2.0 \mathrm{~mL}, 15.7 \mathrm{mmol})$, and the mixture was stirred at room temperature for $2 \mathrm{~h} .58,59$ The solvent was removed in vacuo, resulting in a tan solid $\mathbf{3}$, which was dissolved in $\mathrm{CH}_{2} \mathrm{Cl}_{2}(20 \mathrm{~mL})$. Following the addition of triethylamine $(2.6 \mathrm{~g}, 3.6 \mathrm{~mL}$, $26.1 \mathrm{mmol})$ at $0{ }^{\circ} \mathrm{C}$, trifluoromethanesulfonic anhydride $(2.8 \mathrm{~g}, 2.7 \mathrm{~mL}, 15.7 \mathrm{mmol})$ was added dropwise and the mixture was warmed to room temperature and allowed to stir for 1 h. The mixture was then diluted with diethyl ether, quenched with $1 \mathrm{M} \mathrm{HCl}$, and washed with saturated sodium bicarbonate and brine. The organic layer was dried over $\mathrm{MgSO}_{4}$ and then concentrated, resulting in the desired product $4(4.5 \mathrm{~g}, 95 \%) .{ }^{1} \mathrm{H}$ NMR $(400 \mathrm{MHz}$, $\left.\mathrm{CDCl}_{3}\right) \delta 1.57(\mathrm{~d}, 3 \mathrm{H}), 3.65(\mathrm{~s}, 3 \mathrm{H}), 3.89(\mathrm{q}, 1 \mathrm{H}), 7.34(\mathrm{dd}, J=4,8 \mathrm{~Hz}, 1 \mathrm{H}), 7.52(\mathrm{dd}, J=4$, $8 \mathrm{~Hz}, 1 \mathrm{H}), 7.70(\mathrm{~d}, J=4 \mathrm{~Hz}, 1 \mathrm{H}), 7.77(\mathrm{~s}, 1 \mathrm{H}), 7.81(\mathrm{~d}, J=8 \mathrm{~Hz}, 1 \mathrm{H}), 7.86(\mathrm{~d}, J=8 \mathrm{~Hz}$, 1H). MS $m / z .363(\mathrm{M}+\mathrm{H})^{+}$.

2-(6-Ethylnaphthalen-2-yl)propanoic Acid, 5-(S)-Methyl 2-(6(trifluoromethylsulfonyloxy)naphthalen-2-yl)propyl ester $4(4.2 \mathrm{~g}, 11.6 \mathrm{mmol})$ and $1 \mathrm{M}$ of cesium carbonate $(20 \mathrm{~mL})$ were added to a solution of potassium vinyltrifluoroborate $(2.4 \mathrm{~g}$, $17.5 \mathrm{mmol})$ in EtOH $(100 \mathrm{~mL}$ ). Then tetrakis(triphenylphosphine) palladium (672 mg, 0.59 $\mathrm{mmol})$ and triethylamine $(2.4 \mathrm{~g}, 3.2 \mathrm{~mL}, 23.8 \mathrm{mmol})$ were added to the mixture and stirred $50{ }^{\circ} \mathrm{C}$ for $16 \mathrm{~h}$. The reaction mixture was cooled to room temperature, water $(100 \mathrm{~mL})$ was added, and the resulting mixture was stirred at room temperature for $30 \mathrm{~min}$. The reaction mixture was filtered, resulting in (S)-methyl 2-(6-vinylnaphthalen-2-yl)propanoate as a brown solid ( $2 \mathrm{~g}$ ), which was used directly to the next step without further purification. To a round-bottom flask purged with argon was added THF ( $35 \mathrm{~mL})$, palladium(II) acetate (52 $\mathrm{mg}, 0.24 \mathrm{mmol})$, and tri-tert-butyl phosphine ( $94 \mathrm{mg}, 113 \mathrm{~mL}, 0.46 \mathrm{mmol})$. This was brought to reflux and allowed to stir for $30 \mathrm{~min}$. The reaction was then cooled, and $(S)$ methyl 2-(6-vinyl naphthalen-2-yl)propanoate $(2 \mathrm{~g}, 8.9 \mathrm{mmol})$ and formic acid $(2.7 \mathrm{~g}, 2.3$ $\mathrm{mL}, 59 \mathrm{mmol}$ ) were added to the reaction mixture. The mixture was again brought to reflux for $30 \mathrm{~min}$, then cooled to room temperature and allowed to stir for $12 \mathrm{~h}$. The reaction mixture was filtered through a bed of Celite and then concentrated in vacuo to give the crude (S)-methyl 2-(6-ethylnaphthalen-2-yl)propanoate $(700 \mathrm{mg}$ ), which was added to $14 \mathrm{~mL}$ of a $3 \mathrm{M} \mathrm{KOH}$ solution in $\mathrm{MeOH}$. The reaction was held at reflux for $3 \mathrm{~h}$, then cooled and quenched with water. The reaction mixture was extracted with ethyl ether $(3 \times)$. The aqueous layer was then acidified with $1 \mathrm{M} \mathrm{HCl}$ and then extracted into ethyl ether $(3 \times)$, washed with brine, dried with $\mathrm{MgSO}_{4}$, and concentrated under reduced pressure to give a crude residue, which was purified by column chromatography ( $n$-Hex:EtOAc $4: 1)$ to afford the pure racemic product 5 (450 $\mathrm{mg}$, yield 94\% last step, purity 99.4\%, HPLC retention time 11.93 min, melting point $\left.120-122^{\circ} \mathrm{C}\right) .{ }^{1} \mathrm{H}$ NMR $\left(600 \mathrm{MHz}, \mathrm{DMSO}-d_{6}\right) 1.18(\mathrm{t}, J=5.5 \mathrm{~Hz}, 3 \mathrm{H})$, $1.38(\mathrm{~d}, J=6 \mathrm{~Hz}, 3 \mathrm{H}), 2.68(\mathrm{q}, J=4.5 \mathrm{~Hz}, 2 \mathrm{H}), 3.75(\mathrm{q}, J=4.5 \mathrm{~Hz}, 1 \mathrm{H}), 7.30(\mathrm{dd}, J=7.5$, $2.5 \mathrm{~Hz}, 1 \mathrm{H}), 7.34(\mathrm{dd}, J=7.5,2.5 \mathrm{~Hz}, 1 \mathrm{H}), 7.58(\mathrm{~s}, 1 \mathrm{H}), 7.66(\mathrm{~s}, 1 \mathrm{H}), 7.71-7.73(\mathrm{~m}$, $2 \mathrm{H}) .{ }^{13} \mathrm{C}$ NMR (150.9 MHz, DMSO- $\left.d_{6}\right)$ 15.98, 18.90, 28.75, 45.19, 125.47, 125.94, 126.43, 127.74, 127.92, 128.03, 131.98, 132.70, 138.41, 141.66, 175.86. HRMS: $\mathrm{m} / \mathrm{z}$ calcd for $\mathrm{C}_{15} \mathrm{H}_{16} \mathrm{O}_{2}(\mathrm{M}-\mathrm{H})^{-} 227.1078$, found 227.1079.

2-(6-Ethoxynaphthalen-2-yl)propanoic Acid, 6-Potassium hydroxide (828 mg, 14.8 $\mathrm{mmol})$ in $4 \mathrm{~mL}$ of methanol was added to a round-bottom flask. (S)-Methyl 2-(6- 
hydroxynaphthalen-2-yl)propyl methyl ester 3 ( $2.3 \mathrm{~g}, 9.8 \mathrm{mmol})$ in DMF ( $25 \mathrm{~mL})$ was then added to the flask. The reaction was then allowed to stir at room temperature for $30 \mathrm{~min}$. Iodoethane $(3.0 \mathrm{~g}, 1.5 \mathrm{~mL}, 19.6 \mathrm{mmol})$ was added, which was allowed to stir at room temperature for $3 \mathrm{~h}$. The reaction mixture was quenched with water and extracted with $\mathrm{CH}_{2} \mathrm{Cl}_{2}(3 \times)$, and the organic layer was then dried over $\mathrm{MgSO}_{4}$, filtered, and finally concentrated in vacuo the crude product as a yellow solid ( $450 \mathrm{~g})$, to which was added $8 \mathrm{~mL}$ of a $3 \mathrm{M} \mathrm{KOH}$ solution in $\mathrm{MeOH}$. The reaction was held at reflux for $2 \mathrm{~h}$, then cooled and quenched with water. The reaction mixture was extracted with ethyl ether $(3 \times)$. The aqueous layer was then acidified with $1 \mathrm{M} \mathrm{HCl}$ and then extracted into ethyl ether $(3 \times)$, washed with brine, dried with $\mathrm{MgSO}_{4}$, and concentrated under reduced pressure to give pure racemic product as an off-white solid 6 (360 mg, yield $85 \%$ last step, purity 98\%, HPLC retention time $11.28 \mathrm{~min}$, melting point $\left.148-150{ }^{\circ} \mathrm{C}\right) .{ }^{1} \mathrm{H}$ NMR (600 MHz, DMSO- $\left.d_{6}\right) 1.44$ (t, $J=6$ $\mathrm{Hz}, 3 \mathrm{H}), 1.49$ (d, $J=6.5 \mathrm{~Hz}, 3 \mathrm{H}), 3.85$ (q, $J=4.5 \mathrm{~Hz}, 1 \mathrm{H}), 4.19$ (q, $J=4.5 \mathrm{~Hz}, 1 \mathrm{H}), 7.20$ (dd, $J=2,8.5 \mathrm{~Hz}, 1 \mathrm{H}), 7.32(\mathrm{~d}, J=2 \mathrm{~Hz}, 1 \mathrm{H}), 7.44(\mathrm{dd}, J=2,8.5 \mathrm{~Hz}, 1 \mathrm{H}), 7.76(\mathrm{~s}, 1 \mathrm{H})$, $7.78(\mathrm{~d}, J=8.5,1 \mathrm{H}), 7.85(\mathrm{~d}, J=8.5,1 \mathrm{H}) .{ }^{13} \mathrm{C}$ NMR $\left(150.9 \mathrm{MHz}\right.$, DMSO- $\left.d_{6}\right) 15.10,18.92$, 45.06, 63.54, 106.83, 119.37, 126.00, 126.83, 127.28, 128.80, 129.56, 133.73, 136.74, 156.79, 175.95. HRMS: $m / z$ calcd for $\mathrm{C}_{15} \mathrm{H}_{16} \mathrm{O}_{3}(\mathrm{M}-\mathrm{H})^{-} 243.1027$, found 243.1026 .

(S)-Methyl 2-(6-(Triisopropylsilylthio)naphthalen-2-yl)-propanoate, 7-To a solution of (S)-methyl 2-(6-(trifluoromethylsulfonyloxy)naphthalen-2-yl)propyl methyl ester $4(3 \mathrm{~g}, 8.3 \mathrm{mmol})$ in benzene $(20 \mathrm{~mL})$ was added $\mathrm{Pd}\left(\mathrm{PPh}_{3}\right)_{4}(0.95 \mathrm{~g}, 0.8 \mathrm{mmol})$ and sodium triisopropylsilanethiolate ${ }^{60}(2.1 \mathrm{~g}, 9.9 \mathrm{mmol})$ dissolved in THF $(10 \mathrm{~mL})$. The solution was refluxed for $4 \mathrm{~h}$, then quenched with water and extracted with ethyl acetate. The organic layer was dried over $\mathrm{MgSO}_{4}$ and concentrated. The crude product was purified by flash chromatography using 10:1 hexane:ethyl acetate to give pure product $(2.9 \mathrm{~g}, 87 \%) .{ }^{1} \mathrm{H}$ NMR $\left(400 \mathrm{MHz}, \mathrm{CDCl}_{3}\right) \delta 1.10(\mathrm{~d}, 18 \mathrm{H}), 1.25(\mathrm{~m}, 3 \mathrm{H}), 3.65(\mathrm{~s}, 3 \mathrm{H}), 3.86(\mathrm{q}, 1 \mathrm{H}), 7.31(\mathrm{~m}, 2 \mathrm{H})$, $7.41(\mathrm{dd}, J=4,8 \mathrm{~Hz}, 1 \mathrm{H}), 7.54(\mathrm{dd}, J=4,8 \mathrm{~Hz}, 1 \mathrm{H}), 7.67(\mathrm{~m}, 2 \mathrm{H}) . \mathrm{MS} m / z .403(\mathrm{M}+\mathrm{H})^{+}$.

(S)-Methyl 2-(6-(Methylthio)naphthalen-2-yl)propanoate, 8-To $15 \mathrm{~mL}$ of THF was added (S)-methyl 2-(6-(triisopropylsilylthio)-naphthalen-2-yl)propanoate 7 (2.5 g, 6.2 $\mathrm{mmol})$ followed by tetrabutylammonium fluoride $(3.3 \mathrm{~g}, 3.6 \mathrm{~mL}, 12.4 \mathrm{mmol})$. The mixture was allowed to stir at room temperature for $2 \mathrm{~h}$. Methyl iodide ( $2.6 \mathrm{~g}, 1.2 \mathrm{~mL}, 18.6 \mathrm{mmol}$ ) was then added, and the resulting mixture was stirred for an additional $2 \mathrm{~h}$ at room temperature. The reaction mixture was extracted with ethyl ether, dried over $\mathrm{MgSO}_{4}$, and concentrated in vacuo. The crude product 8 was purified by flash chromatography using 7:1 hexane:ethyl acetate to give pure product $(1.2 \mathrm{~g}, 75 \%) .{ }^{1} \mathrm{H} \mathrm{NMR}\left(400 \mathrm{MHz}, \mathrm{CDCl}_{3}\right) \delta 1.58$ (d, 3H), 2.57 (s, 3H), 3.67 (s, 3H), $3.87(\mathrm{q}, 1 \mathrm{H}), 7.37$ (dd, $J=4,8 \mathrm{~Hz}, 1 \mathrm{H}), 7.42$ (dd, $J=4,8$ $\mathrm{Hz}, 1 \mathrm{H}), 7.58(\mathrm{~s}, 1 \mathrm{H}), 7.67(\mathrm{~s}, 2 \mathrm{H}), 7.70(\mathrm{~d}, J=8 \mathrm{~Hz}, 1 \mathrm{H}) . \mathrm{MS} \mathrm{m} / \mathrm{z} .261(\mathrm{M}+\mathrm{H})^{+}$

2-(6-(Methylthio)naphthalen-2-yl)propanoic Acid, 9-To (S)-methyl 2-(6(methylthio)naphthalen-2-yl)propanoate 8 ( $975 \mathrm{mg}, 3.7 \mathrm{mmol}$ ) was added $20 \mathrm{~mL}$ of a $3 \mathrm{M}$ $\mathrm{KOH}$ solution in $\mathrm{MeOH}$. The reaction was refluxed for $2 \mathrm{~h}$, cooled, and then quenched with water. Following extraction with ethyl ether, the aqueous layer was acidified with $1 \mathrm{M} \mathrm{HCl}$ and then extracted into ethyl ether, washed with brine, dried with $\mathrm{MgSO}_{4}$, and concentrated under reduced pressure to give pure product $9(876 \mathrm{mg}$, yield $95 \%$, purity $99.1 \%$, HPLC 
retention time $11.39 \mathrm{~min}$, melting point $\left.172-174{ }^{\circ} \mathrm{C}\right) .{ }^{1} \mathrm{H}$ NMR $\left(600 \mathrm{MHz}, \mathrm{DMSO}-d_{6}\right) \delta$ $1.45(\mathrm{~d}, J=6.5 \mathrm{~Hz}, 3 \mathrm{H}), 2.57(\mathrm{~s}, 3 \mathrm{H}), 3.82(\mathrm{q}, J=5 \mathrm{~Hz}, 1 \mathrm{H}), 7.38(\mathrm{dd}, J=2,8.5 \mathrm{~Hz}, 1 \mathrm{H})$, 7.45 (dd, $J=2,8.5 \mathrm{~Hz}, 1 \mathrm{H}), 7.68(\mathrm{~s}, 1 \mathrm{H}), 7.74(\mathrm{~s}, 1 \mathrm{H}), 7.79-7.82(\mathrm{~m}, 2 \mathrm{H}) .{ }^{13} \mathrm{C}$ NMR $(150.9$ MHz, DMSO- $\left.d_{6}\right) 15.12,18.85,45.18,63.54,122.67,125.84,127.19,127.32,128.47$, 131.14, 133.02, 136.13, 138.55, 175.79. HRMS: $\mathrm{m} / \mathrm{z}$ calcd for $\mathrm{C}_{14} \mathrm{H}_{14} \mathrm{O}_{2} \mathrm{~S}(\mathrm{M}-$ H) ${ }^{-} 245.0642$, found 245.0637 .

2-(6-(Methylsulfinyl)naphthalen-2-yl)propanoic Acid, 10-2-(6-

(Methylthio)naphthalen-2-yl)propanoic acid $9(65 \mathrm{mg}, 0.26 \mathrm{mmol})$ was dissolved in $8 \mathrm{~mL}$ of dichloromethane. To this solution was added $m$-chloroperoxybenzoic acid $(64 \mathrm{mg}, 0.29$ $\mathrm{mmol}$ ), which was allowed to stir at $0{ }^{\circ} \mathrm{C}$ for $1 \mathrm{~h}$. The reaction mixture was extracted with ethyl ether, dried over $\mathrm{MgSO}_{4}$, and concentrated in vacuo. The crude product was purified by flash chromatography using 10:1 dichloromethane: methanol to give pure product $\mathbf{1 0}$ (46 mg, yield $62 \%$, purity $98.6 \%$, HPLC retention time $7.16 \mathrm{~min}$, melting point $\left.130-132{ }^{\circ} \mathrm{C}\right) .{ }^{1} \mathrm{H}$ NMR $\left(600 \mathrm{MHz}, \mathrm{DMSO}-d_{6}\right) \delta ; 1.40(\mathrm{~d}, J=6.5 \mathrm{~Hz}, 3 \mathrm{H}), 2.74(\mathrm{~s}, 3 \mathrm{H}), 3.83$ (q, $J=5.5 \mathrm{~Hz}$, $1 \mathrm{H}), 7.50(\mathrm{dd}, J=2.5,8.5 \mathrm{~Hz}, 1 \mathrm{H}), 7.63(\mathrm{dd}, J=2,8.5 \mathrm{~Hz}, 1 \mathrm{H}), 7.83(\mathrm{~s}, 2 \mathrm{H}), 7.98(\mathrm{dd}, J=$ $2.5,8.5 \mathrm{~Hz}, 1 \mathrm{H}), 8.16(\mathrm{~s}, 1 \mathrm{H}) .{ }_{13} \mathrm{C}$ NMR (150.9 MHz, DMSO- $\left.d_{6}\right)$ 18.81, 43.50, 45.28, $120.83,123.79,126.45,127.86,127.86,129.29,131.10,133.11,141.20,143.96,175.59$. HRMS: $m / z$ calcd for $\mathrm{C}_{14} \mathrm{H}_{14} \mathrm{O}_{3} \mathrm{~S}(\mathrm{M}+\mathrm{H})^{+} 263.0736$, found 263.0741 .

\section{2-(6-(Methylsulfonyl)naphthalen-2-yl)propanoic Acid, 11-2-(6-}

(Methylthio)naphthalen-2-yl)propanoic acid $9(82.5 \mathrm{mg}, 0.33 \mathrm{mmol})$ was dissolved in $10 \mathrm{~mL}$ of acetone:water (2:1). To this solution was added Oxone ( $445.5 \mathrm{mg}, 0.73 \mathrm{mmol}$ ), which was allowed to stir at room temperature for $2 \mathrm{~h}$. The reaction mixture was extracted with ethyl ether (3x), dried over $\mathrm{MgSO}_{4}$, and concentrated in vacuo to give pure product 11 (56 $\mathrm{mg}$, yield $60 \%$, purity $97.8 \%$, HPLC retention time $8.78 \mathrm{~min}$, melting point $\left.180-182{ }^{\circ} \mathrm{C}\right) .{ }^{1} \mathrm{H}$ NMR (600 MHz, DMSO- $\left.d_{6}\right) \delta 1.45(\mathrm{~d}, J=6 \mathrm{~Hz}, 1 \mathrm{H}), 3.24(\mathrm{~s}, 3 \mathrm{H}), 3.92(\mathrm{q}, J=5.5 \mathrm{~Hz}, 1 \mathrm{H})$, $7.61(\mathrm{dd}, J=2.5,8.5 \mathrm{~Hz}, 1 \mathrm{H}), 7.91(\mathrm{dd}, J=2.5,8.5 \mathrm{~Hz}, 1 \mathrm{H}), 7.94(\mathrm{~s}, 1 \mathrm{H}), 8.13-8.14(\mathrm{~m}$, $2 \mathrm{H}), 8.51(\mathrm{~s}, 1 \mathrm{H}) .{ }^{13} \mathrm{C}$ NMR $\left(150.9 \mathrm{MHz}, \mathrm{DMSO}-d_{6}\right) 18.75,44.05,45.37,122.93,126.40$, 128.34, 128.41, 129.78, 130.04, 131.16, 135.26, 138.16, 142.89, 175.44. HRMS: $\mathrm{m} / \mathrm{z}$ calcd for $\mathrm{C}_{14} \mathrm{H}_{14} \mathrm{O}_{4} \mathrm{~S}(\mathrm{M}+\mathrm{H})^{+} 279.0686$, found 279.0926 .

2-(6-Methoxynaphthalen-2-yl)butanoic Acid, 14-To a flask charged with $18 \mathrm{~mL}$ of THF and purged with argon was added magnesium ribbon $(435.6 \mathrm{mg}, 18 \mathrm{mmol})$ and a crystal of iodine. To this solution was added 2-bromo-6-methoxynaphthalene 12 (3.6 g, 15 $\mathrm{mmol}$ ) in $18 \mathrm{~mL}$ of THF. An off-brown color appeared, and the reaction was allowed to reflux for $1 \mathrm{~h}$. The reaction was then allowed to cool, and methyl 2- bromobutyrate (5.4 g, $3.4 \mathrm{~mL}, 30.2 \mathrm{mmol}$ ) was added. Following $2 \mathrm{~h}$ of reflux, the reaction was quenched with 1 $\mathrm{M} \mathrm{HCl}$, then extracted with ethyl ether ( $3 \times$ ), washed with brine, dried with $\mathrm{MgSO}_{4}$, and concentrated under reduced pressure. The crude mixture was suspended in $18 \mathrm{~mL}$ of a $3 \mathrm{M}$ $\mathrm{KOH}$ solution in $\mathrm{MeOH}$, held at reflux for $2 \mathrm{~h}$, cooled, and then quenched with water. The reaction mixture was extracted with ethyl ether $(3 x)$. The aqueous layer was then acidified with $1 \mathrm{M} \mathrm{HCl}$, extracted into ethyl ether (3×), washed with brine, dried with $\mathrm{MgSO}_{4}$, and concentrated under reduced pressure to give crude product 14 . The product was purified using HPLC on a C18 column (2 g, yield 55\%, purity 99.8\%, HPLC retention time $15.8 \mathrm{~min}$, 
melting point $\left.115-117{ }^{\circ} \mathrm{C}\right)$ to give pure racemic product. ${ }^{1} \mathrm{H}$ NMR $\left(600 \mathrm{MHz}, \mathrm{DMSO}-d_{6}\right) \delta$ $0.84(\mathrm{t}, J=7 \mathrm{~Hz}, 3 \mathrm{H}), 1.74-1.77(\mathrm{~m}, 1 \mathrm{H}), 2.02-2.06(\mathrm{~m}, 1 \mathrm{H}), 3.52(\mathrm{t}, J=5.5 \mathrm{~Hz}, 1 \mathrm{H}), 3.86$ (s, $3 \mathrm{H}), 7.11(\mathrm{dd}, J=2.5,8.7 \mathrm{~Hz}, 1 \mathrm{H}), 7.28(\mathrm{~d}, J=2.5 \mathrm{~Hz}, 1 \mathrm{H}), 7.40(\mathrm{dd}, J=2.5,8.7 \mathrm{~Hz}$, $1 \mathrm{H}), 7.71(\mathrm{~s}, 1 \mathrm{H}), 7.76-7.80(\mathrm{~m}, 2 \mathrm{H}) .{ }^{13} \mathrm{C}$ NMR $\left(150.9 \mathrm{MHz}, \mathrm{DMSO}-d_{6}\right) 12.56,26.50$, 53.01, 55.63, 106.17, 119.16, 126.69, 126.99, 127.31, 128.86, 129.57, 133.78, 135.24, 157.56, 175.40. HRMS: $m / z$ calcd for $\mathrm{C}_{15} \mathrm{H}_{16} \mathrm{O}_{3}(\mathrm{M}-\mathrm{H})^{-} 243.1027$, found 243.1024 .

2-(6-Methoxynaphthalen-2-yl)-N-(methylsulfonyl)butanamide, 15-To an ice-cold mixture $\left(0-5{ }^{\circ} \mathrm{C}\right)$ of 2-(6-methoxynaphthalen-2-yl)butanoic acid $\mathbf{1 4} .{ }^{42}(87 \mathrm{mg}, 0.39 \mathrm{mmol})$ in dry $\mathrm{CH}_{2} \mathrm{Cl}_{2}(3 \mathrm{~mL})$ under argon was added $1,1^{\prime}$-carbonyldiimidazole $(63 \mathrm{mg}, 0.39$ $\mathrm{mmol}$ ). After the reaction mixture was stirred for $2 \mathrm{~h}$ at $0-5{ }^{\circ} \mathrm{C}$, methanesulfonamide (33 $\mathrm{mg}, 0.39 \mathrm{mmol}$ ) and diazabicyclo[5.4.0]-undec-7-ene (59 $\mathrm{mg}, 0.39 \mathrm{mmol})$ (1 equiv) were added. The mixture was left stirring for another $4 \mathrm{~h}$ at ambient temperature before it was quenched by the addition of glacial acetic acid ( $52 \mathrm{uL}$ ) and diluted with additional $\mathrm{CH}_{2} \mathrm{Cl}_{2}$ $(1 \mathrm{~mL})$. The organic layer was separated and washed with $10 \% \mathrm{NaH}_{2} \mathrm{PO}_{4}$ buffer $(\mathrm{pH} 4)(2 \times$ $3 \mathrm{~mL})$ and water $(3 \times 3 \mathrm{~mL})$, dried over $\mathrm{Na}_{2} \mathrm{SO}_{4}$, filtered, and concentrated under reduced pressure to give a crude residue. The raw product was purified by flash chromatography $\left(\mathrm{SiO}_{2}\right.$, ethyl acetate/hexane gradient) to afford the product (52 mg, yield $45 \%$, purity $98.5 \%$, HPLC retention time $11.20 \mathrm{~min}$, melting point $144-146^{\circ} \mathrm{C}$ ) of the pure title compound. ${ }^{1} \mathrm{H}$ NMR $\left(600 \mathrm{MHz}\right.$, DMSO- $\left.d_{6}\right) \delta 0.82(\mathrm{t}, J=7.46 \mathrm{~Hz}, 3 \mathrm{H}), 1.73-1.75(\mathrm{~m}, 1 \mathrm{H}), 2.02-2.06(\mathrm{~m}$, $1 \mathrm{H}), 3.18(\mathrm{~s}, 3 \mathrm{H}), 3.61(\mathrm{t}, J=7.04 \mathrm{~Hz}, 1 \mathrm{H}), 3.85(\mathrm{~s}, 3 \mathrm{H}), 7.14(\mathrm{dd}, J=9.5,2.1 \mathrm{~Hz}, 1 \mathrm{H}), 7.27$ (d, $J=2.2 \mathrm{~Hz}, 1 \mathrm{H}), 7.39$ (dd, $J=9.2,2.0 \mathrm{~Hz}, 1 \mathrm{H}), 7.69(\mathrm{~s}, 1 \mathrm{H}), 7.77(\mathrm{~d}, J=9.7 \mathrm{~Hz}, 1 \mathrm{H})$, $7.79(\mathrm{~d}, J=9.8 \mathrm{~Hz}, 1 \mathrm{H}) .{ }^{13} \mathrm{C}$ NMR $\left(150.9 \mathrm{MHz}\right.$, DMSO- $\left.d_{6}\right) 12.37,26.37,41.35,53.35$, 55.61, 106.14, 119.22, 126.78, 126.84, 127.38, 128.75, 129.62, 133.88, 134.24, 157.67, 173.72. HRMS: $\mathrm{m} / z$ calcd for $\mathrm{C}_{16} \mathrm{H}_{19} \mathrm{NO}_{4} \mathrm{~S}(\mathrm{M}-\mathrm{H})^{-} 320.0962$, found 320.0966 .

\section{Determination of the Configuration of Naproxen Enantiomers 9a and $9 \mathrm{~b}$ and}

14a and 14b-The configuration of compounds was inferred by comparing the order of elution of the two enantiomers of compound $9(9 \mathbf{a}$ and $9 \mathbf{b})$ and the two enantiomers of compound 14 (14a and 14b) from chiral columns with the order of elution of naproxen $(S$ isomer) and $R$-naproxen from the same column. A mixture of $R$ - and $S$-naproxen, $R$ naproxen, $S$-naproxen, compound $\mathbf{9 , 9 a}$, and $9 \mathrm{~b}$ were resolved on a Chiral AD-RH column $(150 \mathrm{~mm} \times 4.6 \mathrm{~mm})$ using an isocratic elution method with a mobile phase of $60 \%$ HPLC grade water: $40 \%$ acetonitrile containing $0.1 \%$ formic acid. By contrast, a mixture of $R$ - and $S$-naproxen, $R$-naproxen, $S$-naproxen, compound $14,14 \mathrm{a}$, and $14 \mathrm{~b}$ were resolved on a ChiralPak 1C $(150 \mathrm{~mm} \times 4.6 \mathrm{~mm})$ column using an isocratic elution method. The mobile phase was $0.05 \%$ TFA in hexane:0.05\% TFA in EtOH (98.5:1.5\%) with a flow rate of 0.5 $\mathrm{mL} / \mathrm{min}$ at room temperature (see Supporting Information). Absorbance was monitored at $230 \mathrm{~nm}$ except for compounds $\mathbf{9 a}$ and $\mathbf{9 b}$ where absorbance was monitored at $254 \mathrm{~nm}$.

\section{Ligand Alignment and Molecular Docking}

The structural models of the ligand-enzyme interactions used in the ligand alignment and docking experiments are based on the existing crystal structures of AKR1C3.NADP ${ }^{+}$ complexed with $R$-naproxen, AKR1C3.NADP ${ }^{+}$complexed with $S$-naproxen, and AKR1C2.NADP ${ }^{+}$complexed with $S$-naproxen. In the first stage, $R$-naproxen was docked to 
the AKR1C2.NADP ${ }^{+}$structure to generate AKR1C2.NADP ${ }^{+}$complexed with $R$-naproxen because no crystal structure of this complex has been published. The second round of molecular modeling aligned $\mathbf{1 4 a}$ and $\mathbf{1 4 b}$ to their template ligand-enzyme structures. The results were overlaid to compare differences in the binding interactions of naproxen analogues in AKR1C2 and AKR1C3. For complete details, see Supporting Information

\section{Enzyme Purification}

Homogenous recombinant enzymes AKR1C1-4 were prepared and purified as previously described. ${ }^{61}$ Enzymes were purified to constant specific activity and their purity established by SDS-PAGE, see Supporting Information. All AKR enzymes were stored at $-80^{\circ} \mathrm{C}$ in 20 $\mathrm{mM}$ potassium phosphate buffer $\mathrm{pH} 7.0$ containing 30\% glycerol, $1 \mathrm{mM}$ EDTA, and $1 \mathrm{mM}$ $\beta$-mercaptoethanol. Under standard assay conditions, the specific activity of AKR1C1 for the $\mathrm{NAD}^{+}$dependent oxidation of 1-acenaphthenol (Sigma) was $2.0 \mu \mathrm{mol} \mathrm{min}{ }^{-1} \mathrm{mg}^{-1}$. The specific activities of AKR1C2 and AKR1C3 for the NAD ${ }^{+}$dependent oxidation of $S$-tetralol (Sigma) were 1.5 and $2.0 \mu \mathrm{mol} \mathrm{min}^{-1} \mathrm{mg}^{-1}$, respectively, and the specific activity of AKR1C4 for the $\mathrm{NAD}^{+}$dependent oxidation of androsterone (Steraloids) was $0.3 \mu \mathrm{mol}$ $\mathrm{min}^{-1} \mathrm{mg}^{-1}$ and are in agreement with previously published values. The specific activities of AKR1C enzymes were determined by measuring the formation of NADH at $340 \mathrm{~nm}$ using a Beckman DU640 spectrophotometer. A typical assay solution contained $100 \mathrm{mM}$ potassium phosphate $\mathrm{pH}$ 7.0, $2.3 \mathrm{mM} \mathrm{NAD}^{+}, 200 \mu \mathrm{M}$ 1-acenaphthenol for AKR1C1, $3.0 \mathrm{mM} S$-tetralol for AKR1C2 and 1C3, and $75 \mu \mathrm{M}$ androsterone for AKR1C4, 4\% acetonitrile (v/v). The mixtures were incubated at $25{ }^{\circ} \mathrm{C}$ (AKR1C1 and 1C4) or $37{ }^{\circ} \mathrm{C}$ (AKR1C2 and $1 \mathrm{C} 3$ ) for 3 min, followed by adding a serial dilution of enzyme solution to a final volume of $1 \mathrm{~mL}$ to initiate the reaction. After continuously monitoring for $5 \mathrm{~min}$, the increase in UV absorption using different concentrations of enzyme were recorded to calculate the initial velocity of substrate oxidation and determine enzyme-specific activity.

COX-1 was purified to homogeneity from ram seminal vesicles. ${ }^{62}$ The purity of the enzyme was assessed by SDS-PAGE (see Supporting Information). The specific activity of COX-1 for the conversion of arachidonic acid to prostaglandin $\mathrm{H}_{2}\left(\mathrm{PGH}_{2}\right)$ was coupled to the oxidation of $N, N, N^{\prime}, N^{\prime}$-tetramethyl-1,4-phenylenediamine (TMPD) and was found to be. $1.0 \mu \mathrm{mol} \mathrm{min}{ }^{-1} \mathrm{mg}^{-1}$. The specific activity of COX-1 enzyme was determined by measuring the formation of oxidized TMPD at $610 \mathrm{~nm}$ using Synergy 2 plate reader (BioTek). A typical assay solution $(200 \mu \mathrm{L})$ contained $100 \mathrm{mM}$ Tris- $\mathrm{HCl}(\mathrm{pH}$ 8.0), $2 \mu \mathrm{M}$ Hemin (Sigma), 5\% DMSO, a serial dilution of COX-1 enzyme solution, $80 \mu \mathrm{M}$ TMPD (Sigma), and $20 \mu \mathrm{M}$ arachidonic acid (Sigma). Reagents were mixed and incubated at $25{ }^{\circ} \mathrm{C}$ for 5 min followed by adding a mixture of TMPD and arachidonic acid to initiate the reaction. Specific activity was determined based on the initial velocity of the reduction of $\mathrm{PGG}_{2}$ formed in the reaction.

\section{Enzyme Assays}

S-Tetralol Oxidation Assay-The inhibitory potency of an individual compound against the AKR1C isoforms was determined by monitoring the $\mathrm{NADP}^{+}$dependent oxidation of $S$ tetralol catalyzed by the AKR1C enzymes using a Synergy 2 plate reader (BioTek). Reaction systems $(200 \mu \mathrm{L})$ contained $100 \mathrm{mM}$ potassium phosphate buffer (pH 7.0), 4\% DMSO, 200 
$\mu \mathrm{M} \mathrm{NADP}^{+}$, a serial dilution of compounds, $S$-tetralol, and AKR1C enzymes. The concentration of $S$-tetralol used in the inhibition assays using AKR1C1, 1C2, 1C3, and 1C4 was $5,22.5,165$, and $25 \mu \mathrm{M}$, respectively, which was equal to their $K_{\mathrm{m}}$ values in order to make a direct comparison of $\mathrm{IC}_{50}$ values. The concentration of AKR1C1, $1 \mathrm{C} 2,1 \mathrm{C} 3$, and $1 \mathrm{C} 4$ was $111,86,95$, and $552 \mathrm{nM}$, respectively. Reagents were mixed and incubated at $37^{\circ} \mathrm{C}$ for 10 min followed by adding AKR1C enzymes to initiate the reaction. A continuous fluorometric assay (Ex, $340 \mathrm{~nm}$; Em, $460 \mathrm{mM}$ ) to measure NADPH formation was conducted at $37{ }^{\circ} \mathrm{C}$ for $5 \mathrm{~min}$, and the $\mathrm{IC}_{50}$ value of each compound was calculated as previously described. To determine the pattern of inhibition, five fixed concentrations of $S$ tetralol were used and four different concentrations of inhibitor were used. The equations for COMP, NONCOMP, and UNCOMP were globally fit to the initial velocity data using Grafit 5.0.6.

Reduction of Ketosteroids by Radiochemistry-Compounds were tested for their ability to inhibit the AKR1C3 catalyzed, reduction of $\left[{ }^{3} \mathrm{H}\right]-\Delta^{4}-\mathrm{AD}$ and the AKR1C2 catalyzed reduction of $\left[{ }^{3} \mathrm{H}\right]-5 a-D H T$. Compounds were incubated with purified recombinant enzyme and radiolabeled steroid in $100 \mathrm{mM}$ phosphate buffer, $\mathrm{pH}$ 7.0, and 4\% DMSO at $37^{\circ} \mathrm{C}$. The reaction was initiated by the addition of $1 \mathrm{mM} \mathrm{NADPH}$, and aliquots were removed over time and subsequently quenched by the addition of ice-cold ethyl acetate. The ethyl acetate fraction was extracted and dried in vacuo. Steroid reference standards and extracts were dissolved in $50 \mu \mathrm{L}$ of ethyl acetate and applied to LK6D silica TLC plates (Whatman Inc., Clifton, NJ). TLC plates were developed using a dichloromethane/ethyl acetate $(80: 20 \mathrm{v} / \mathrm{v})$ solution and were scanned with a Bioscan System 200 plate reader (Washington, DC). The percentage of radioactivity in the product peak was calculated assuming that the combined radioactivity in the substrate and product peaks was $100 \%$. Initial velocities were computed by converting the percentage of radioactivity in the product peak by the specific radioactivity of the starting material to generate $\mathrm{pmol} / \mathrm{min}$. The pattern of AKR1C3 inhibition was determined using five fixed concentrations of $\left[{ }^{3} \mathrm{H}\right]-\Delta^{4}$-AD using 5 concentrations of inhibitor. Equations for COMP, NONCOMP, and UNCOMP were fitted to the initial velocity data as described above.

COX-1 Assay-The effect of the compounds on COX-1 activity were determined by monitoring the oxidation of TMPD when coupled to COX catalyzed formation of prostaglandin $\mathrm{H}_{2}\left(\mathrm{PGH}_{2}\right)$ from $\mathrm{PGG}_{2}$ using arachidonic acid as substrate. In brief, $200 \mu \mathrm{L}$ of reaction solution was composed of $100 \mathrm{mM}$ Tris- $\mathrm{HCl}$ (pH 8.0), $2 \mu \mathrm{M}$ Hemin (Sigma), 5\% DMSO, a serial dilution of compounds, COX-1 enzyme (175 nM), $80 \mu$ M TMPD (Sigma), and $20 \mu \mathrm{M}$ arachidonic acid (Sigma). Reagents were mixed and incubated at $25^{\circ} \mathrm{C}$ for $5 \mathrm{~min}$ followed by adding a mixture of TMPD and arachidonic acid to initiate the reaction. A continuous colorimetric assay to measuring TMPD oxidation at $610 \mathrm{~nm}$ was conducted using a Synergy 2 plate reader at $25^{\circ} \mathrm{C}$ for $5 \mathrm{~min}$, and $\mathrm{IC}_{50}$ value of each compound was calculated as previously described. ${ }^{37}$

\section{Cell-Based Assays}

AR-Luciferase Assay-HeLa $13^{63}$ cells stably expressing the AR and a luciferase reporter gene construct were used for this assay as previously described. ${ }^{37,47}$ Briefly, cells 
were cultured in phenol red free media supplemented with 5\% CDFBS (CSS media) for 48 $\mathrm{h}$. The cells were then harvested and plated in a 96-well plate for 6-7 h, after which fresh CSS media (see below) containing $1 \mathrm{nM} 5 \mathrm{a}$-DHT in the presence of inhibitor was added. After $20 \mathrm{~h}$ incubation, the media was removed and the luciferase activity in the cells was measured using the Bright Glo kit (Promega) according to the manufacturer's instructions. Fold induction of luciferase was evaluated relative to untreated cells.

Western Blots-LNCaP cells stably expressing AKR1C3 (LNCaP-AKR1C3 cells) ${ }^{64}$ seeded at a density of $1.5 \times 10^{6}$ cells were plated in $6 \mathrm{~cm}$ dishes containing phenol red free RPMI-1640 media supplemented with 5\% CDFBS, 1\% Pen/Strep, and $2 \mathrm{mM} \mathrm{L-glutamine}$ (CSS media). The cells were incubated for $24 \mathrm{~h}$, after which media was aspirated and fresh CSS media containing $100 \mathrm{nM} \Delta^{4}$-AD plus and minus inhibitors. The cells were incubated for $24 \mathrm{~h}$, after which they were harvested in RIPA lysis buffer supplemented with protease inhibitors at $4{ }^{\circ} \mathrm{C}$. Lysate protein concentration was determined by the Bradford assay using the BIORAD protein dye (Bio-Rad). The samples were subjected to electrophoresis on a $12 \%$ SDS-PAGE gel that was subsequently transferred to a nitrocellulose membrane. The membrane was probed with the appropriate antibodies as follows: anti- $\beta$-tubulin (Millipore, no. 05-661) and anti-PSA (Meridian Life Science, Inc., no. K92110R). Blots were imaged using the ECL reagent (Pierce) and GelDoc XR+ system and Image Lab software (Bio-Rad).

Radiometric Assay of Androgen Metabolism-LNCaP-AKR1C3 cells seeded at a density of $1.5 \times 10^{6}$ cells were plated in 6-well plates in CSS media. The cells were allowed to incubate for $24 \mathrm{~h}$, after which the media was aspirated and fresh CSS media with $7.5 \mathrm{nM}$ $\left(1.26 \mu \mathrm{Ci}\right.$ ) of $\left[{ }^{3} \mathrm{H}\right] \Delta^{4}$-AD and $92.5 \mathrm{nM}$ of cold $\Delta^{4}$-AD (to obtain a final concentration of 100 $\mathrm{nM}$ ) was added in the presence and absence of $30 \mu \mathrm{M}$ of compound 14a in each well. The cells were incubated for $48 \mathrm{~h}$, after which time the media was collected for analysis as previously described. ${ }^{63}$ The media was extracted twice with cold ethyl acetate. To determine radioactivity of each phase, a portion of each fraction was added to Ultima Gold (PerkinElmer Life Sciences) scintillation fluid and analyzed on a TriCarb 2100 (Packard Instruments, PerkinElmer Life Sciences) and all CPM counts were blank-adjusted and reported as corrected cpm. The aqueous phases were acidified to $\mathrm{pH} 6.5$ with acetic acid and subjected to treatment with $400 \mathrm{U}$ of Echerichia coli $\beta$-glucuronidase at $37{ }^{\circ} \mathrm{C}$ for $24 \mathrm{~h}$. The deconjugated androgens were re-extracted as described above, dried in vacuo, and redissolved in $100 \mu \mathrm{L}$ of ethyl acetate for separation on the multichannel LK6D Silica TLC plates. Plates were developed using dichloromethane/ethyl acetate $(80: 20 \mathrm{v} / \mathrm{v})$ and scanned on the BioScan 200 plate reader.

\section{Supplementary Material}

Refer to Web version on PubMed Central for supplementary material.

\section{Acknowledgments}

Supported by P01-CA163227 and P30-ES013508 from the NIH to T.M.P. and by R01-CA89450 and R01GM15431 to L.J.M. We are grateful to Andy Liedtke for synthesis and characterization of some of the early compounds. A provisional patent application was filed for the compounds described on October 22, 2015 at the U.S. Patent Office (US provisional patent application no. 62/244,934). 


\title{
ABBREVIATIONS USED
}

\author{
$\Delta^{4}$-AD $\quad \Delta^{4}$-androstene-3,17-dione \\ AA abiraterone acetate \\ Adione $5 a$-androstane-3,17-dione \\ ADT androgen deprivation therapy \\ AKR1C3 aldo-keto reductase 1C3 \\ AR androgen receptor \\ COX cylcooxygenases $\left(\mathrm{PGH}_{2}\right.$-synthase I and II) \\ CRPC castration resistant prostate cancer \\ 5a-DHT 5a-dihydrotestosterone \\ ENZ enzalutamide \\ NSAID nonsteroidal anit-inflammatory drug \\ PSA prostate specific antigen \\ TLC thin layer chromatography
}

\section{REFERENCES}

1. Knudsen KE, Penning TM. Partners in crime: deregulation of AR activity and androgen synthesis in prostate cancer. Trends Endocrinol. Metab. 2010; 21:315-324. [PubMed: 20138542]

2. Knudsen KE, Scher HI. Starving the addiction: new opportunities for durable suppression of AR signaling in prostate cancer. Clin. Cancer Res. 2009; 15:4792-4798. [PubMed: 19638458]

3. Locke JA, Guns ES, Lubik AA, Adomat HH, Hendy SC, Wood CA, Ettinger SL, Gleave ME, Nelson CC. Androgen levels increase by intratumoral de novo steroidogenesis during progression of castration-resistant prostate cancer. Cancer Res. 2008; 68:6407-6415. [PubMed: 18676866]

4. Montgomery RB, Mostaghel EA, Vessella R, Hess DL, Kalhorn TF, Higano CS, True LD, Nelson PS. Maintenance of intratumoral androgens in metastatic prostate cancer: a mechanism for castration-resistant tumor growth. Cancer Res. 2008; 68:4447-4454. [PubMed: 18519708]

5. Mostaghel EA, Page ST, Lin DW, Fazli L, Coleman IM, True LD, Knudsen B, Hess DL, Nelson CC, Matsumoto AM, Bremner WJ, Gleave ME, Nelson PS. Intraprostatic androgens and androgenregulated gene expression persist after testosterone suppression: therapeutic implications for castration-resistant prostate cancer. Cancer Res. 2007; 67:5033-5041. [PubMed: 17510436]

6. Visakorpi T, Hyytinen E, Koivisto P, Tanner M, Keinänen R, Palmberg C, Palotie A, Tammela T, Isola J, Kallioniemi OP. In vivo amplification of the androgen receptor gene and progression of human prostate cancer. Nat. Genet. 1995; 9:401-406. [PubMed: 7795646]

7. Shi X-B, Ma A-H, Xia L, Kung H-J, de Vere White RW. Fuctional analysis of 44 mutant androgen receptors from human prostate cancer. Cancer Res. 2002; 62:1496-1502. [PubMed: 11888926]

8. Taplin ME, Bubley GJ, Shuster TD, Frantz ME, Spooner AE, Ogata GK, Keer HN, Balk SP. Mutation of the androgen-receptor gene in metastatic androgen-independent prostate cancer. N. Engl. J. Med. 1995; 332:1393-1398. [PubMed: 7723794]

9. Antonarakis ES, Lu C, Wang H, Luber B, Nakazawa M, Roeser JC, Chen Y, Mohammad TA, Chen Y, Fedor HL, Lotan TL, Zheng Q, De Marzo AM, Isaacs JT, Isaacs WB, Nadal R, Paller CJ, 
Denmeade SR, Carducci MA, Eisenberger MA, Luo J. AR-V7 and resistance to enzalutamide and abiraterone in prostate cancer. N. Engl. J. Med. 2014; 371:1028-1038. [PubMed: 25184630]

10. Sprenger CC, Plymate SR. The link between androgen receptor splice variants and castrationresistant prostate cancer. Horm. Cancer. 2014; 5:207-2014. [PubMed: 24798453]

11. O’Donnell A, Judson I, Dowsett M, Raynaud F, Dearnaley D, Mason M, Harland S, Robbins A, Halbert G, Nutley B, Jarman M. Hormonal impact of the 17a-hydroxylase/C(17,20)-lyase inhibitor abiraterone acetate (CB7630) in patients with prostate cancer. Br. J. Cancer. 2004; 90:2317-2325. [PubMed: 15150570]

12. Attard G, Reid AH, Yap TA, Raynaud F, Dowsett M, Settatree S, Barrett M, Parker C, Martins V, Folkerd E, Clark J, Cooper CS, Kaye SB, Dearnaley D, Lee G, de Bono JS. Phase I clinical trial of a selective inhibitor of CYP17, abiraterone acetate, confirms that castration-resistant prostate cancer commonly remains hormone driven. J. Clin. Oncol. 2008; 26:4563-4571. [PubMed: 18645193]

13. Attard G, Reid AH, A’Hern R, Parker C, Oommen NB, Folkerd E, Messiou C, Molife LR, Maier G, Thompson E, Olmos D, Sinha R, Lee G, Dowsett M, Kaye SB, Dearnaley D, Kheoh T, Molina A, de Bono JS. Selective inhibition of CYP17 with abiraterone acetate is highly active in the treatment of castration-resistant prostate cancer. J. Clin. Oncol. 2009; 27:3742-3748. [PubMed: 19470933]

14. Reid AH, Attard G, Danila DC, Oommen NB, Olmos D, Fong PC, Molife LR, Hunt J, Messiou C, Parker C, Dearnaley D, Swennenhuis JF, Terstappen LW, Lee G, Kheoh T, Molina A, Ryan CJ, Small E, Scher HI, de Bono JS. Significant and sustained antitumor activity in post-docetaxel, castration-resistant prostate cancer with the CYP17 inhibitor abiraterone acetate. J. Clin. Oncol. 2010; 28:1489-1495. [PubMed: 20159823]

15. de Bono JS, Logothetis CJ, Molina A, Fizazi K, North S, Chu L, Chi KN, Jones RJ, Goodman OB Jr, Saad F, Staffurth JN, Mainwaring P, Harland S, Flaig TW, Hutson TE, Cheng T, Patterson H, Hainsworth JD, Ryan CJ, Sternberg CN, Ellard SL, Flechon A, Saleh M, Scholz M, Efstathiou E, Zivi A, Bianchini D, Loriot Y, Chieffo N, Kheoh T, Haqq CM, Scher HI. Abiraterone and increased survival in metastatic prostate cancer. N. Engl. J. Med. 2011; 364:1995-2005. [PubMed: 21612468]

16. Cai C, Chen S, Ng P, Bubley GJ, Nelson PS, Mostaghel EA, Marck B, Matsumoto AM, Simon NI, Wang H, Chen S, Balk SP. Intratumoral de novo steroid synthesis activates androgen receptor in castration-resistant prostate cancer and is upregulated by treatment with CYP17A1 inhibitors. Cancer Res. 2011; 71:6503-6513. [PubMed: 21868758]

17. Mostaghel EA, Marck BT, Plymate SR, Vessella RL, Balk SP, Matsumoto AM, Nelson PS, Montgomery RB. Resistance to CYP17A1 inhibition with abiraterone in castration-resistant prostate cancer: induction of steroidogenesis and androgen receptor splice variants. Clin. Cancer Res. 2011; 17:5913-5925. [PubMed: 21807635]

18. Lin H-K, Jez JM, Schlegel BP, Peehl DM, Pachter JA, Penning TM. Expression and characterization of recombinant type $23 a$-hydroxysteroid dehydrogenase (HSD) from human prostate: demonstration of bifunctional $3 a / 17 \beta-H S D$ activity and cellular distribution. Mol. Endocrinol. 1997; 11:1971-1984. [PubMed: 9415401]

19. Penning TM, Burczynski ME, Jez JM, Hung CF, Lin HK, Ma H, Moore M, Palackal N, Ratnam K. Human 3a-hydroxysteroid dehydrogenase isoforms (AKR1C1-AKR1C4) of the aldo-keto reductase superfamily: functional plasticity and tissue distribution reveals roles in the inactivation and formation of male and female sex hormones. Biochem. J. 2000; 351:67-77. [PubMed: 10998348]

20. Mohler JL, Titus MA, Bai S, Kennerley BJ, Lih FB, Tomer KB, Wilson EM. Activation of the androgen receptor by intratumoral bioconversion of androstanediol to dihydrotestosterone in prostate cancer. Cancer Res. 2011; 71:1486-1496. [PubMed: 21303972]

21. Auchus RJ. The backdoor pathway to dihydrotestosterone. Trends Endocrinol. Metab. 2004; 15:432-438. [PubMed: 15519890]

22. Fung K-M, Shea-Samara EH, Wong C, Metwalli A, Krlin R, Bane B, Liu CZ, Yang JT, Pitha JV, Culkin DJ, Kropp BP, Penning TM, Lin H-K. Increased expression of type 23 a-hydroxysteroid dehydrogenase/type 5 17 $\beta$-hydroxysteroid dehydrogenase (AKR1C3) and its relationship with the 
androgen receptor in prostate carcinoma. Endocr.-Relat. Cancer. 2006; 13:169-180. [PubMed: 16601286]

23. Mitsiades N, Sung CC, Schultz N, Danila DC, He B, Eedunuri VK, Fleisher M, Sander C, Sawyers $\mathrm{CL}$, Scher HI. Distinct patterns of dysregulated expression of enzymes involved in androgen synthesis and metabolism in metastatic prostate cancer tumors. Cancer Res. 2012; 72:6142-6152. [PubMed: 22971343]

24. Hamid AH, Pfeiffer MI, Verhaegh GW, Schaafsma E, Brandt A, Sweep FC, Sedelaar JP, Schalken JA. Aldo-keto reductase 1 member C3 (AKR1C3) is a biomarker and therapeutic target for castration-resistant prostate cancer. Mol. Med. 2012; 18:1449-1455.

25. Stanbrough M, Bubley GJ, Ross K, Golub TR, Rubin MA, Penning TM, Febbo PG, Balk SP. Increased expression of genes converting adrenal androgens to testosterone in androgenindependent prostate cancer. Cancer Res. 2006; 66:2815-2825. [PubMed: 16510604]

26. Tian Y, Zhao L, Zhang H, Liu X, Zhao L, Zhao X, Li Y, Li J. AKR1C3 overexpression may serve as a promising biomarker for prostate cancer progression. Diagn. Pathol. 2014; 9:42-48. [PubMed: 24571686]

27. Hofland J, van Weerden WM, Dits NF, Steenbergen J, van Leenders GJ, Jenster G, Schroder FH, de Jong FH. Evidence of limited contributions for intratumoral steroidogenesis in prostate cancer. Cancer Res. 2010; 70:1256-1264. [PubMed: 20086173]

28. Pfeiffer MJ, Smit FP, Sedelaar JP, Schalken JA. Steroidogenic enzymes and stem cell markers are upregulated during androgen deprivation in prostate cancer. Mol. Med. 2011; 17:657-664. [PubMed: 21365123]

29. Powell K, Semaan L, Conley-LaComb MK, Asangani I, Wu Y-M, Ginsburg KB, Williams J, Squire JA, Maddipati KR, Cher ML, Chinni SR. ERG/AKR1C3/AR constitutes a feed-forward loop for AR signaling in prostate cancer cells. Clin. Cancer Res. 2015; 21:2569-2579. [PubMed: 25754347]

30. Yepuru M, Wu Z, Kulkarni A, Yin F, Barrett CM, Kim J, Steiner MS, Miller DD, Dalton JT, Narayanan R. Steroidogenic enzyme AKR1C3 is a novel androgen receptor-selective coactivator that promotes prostate cancer growth. Clin. Cancer Res. 2013; 19:5613-5625. [PubMed: 23995860]

31. Beer TM, Armstrong AJ, Rathkopf DE, Loriot Y, Sternberg CN, Higano CS, Iversen P, Bhattacharya S, Carles J, Chowdhury S, Davis ID, de Bono JS, Evans CP, Fizazi K, Joshua AM, Kim C-S, Kimura G, Mainwaring P, Mansbach H, Miller K, Noonberg SB, Perabo F, Phung D, Saad F, Scher HI, Taplin M-E, Venner PM, Tombal B. for the PREVAIL Investigators. Enzalutamide in metastatic prostate cancer before chemotherapy. N. Engl. J. Med. 2014; 371:424433. [PubMed: 24881730]

32. Scher HI, Beer TM, Higano CS, Anand A, Taplin ME, Efstathiou E, Rathkopf D, Shelkey J, Yu EY, Alumkal J, Hung D, Hirmand M, Seely L, Morris MJ, Danila DC, Humm J, Larson S, Fleisher M, Sawyers CL. Prostate Cancer Foundation/Department of Defense Prostate Cancer Clinical Trials Consortium. antitumour activity of MDV3100 in castration-resistant prostate cancer: a phase 1-2 study. Lancet. 2010; 375:1437-1446. [PubMed: 20398925]

33. Tran C, Ouk S, Clegg NJ, Chen Y, Watson PA, Arora V, Wongvipat J, Smith-Jones PM, Yoo D, Kwon A, Wasielewska T, Welsbie D, Chen CD, Higano CS, Beer TM, Hung DT, Scher HI, Jung ME, Sawyers CL. Development of a second-generation antiandrogen for treatment of advanced prostate cancer. Science. 2009; 324:787-790. [PubMed: 19359544]

34. Byrns MV, Steckelbroeck S, Penning TM. An indomethacin analogue, N-(4-chlorobenzoyl)melatonin, is a selective inhibitor of aldo-keto reductase 1C3 (type $23 a-H S D$, type $517 \beta$-HSD, and prostaglandin F synthase), a potential target for the treatment of hormone dependent and hormone independent malignancies. Biochem. Pharmacol. 2008; 75:484-493. [PubMed: 17950253]

35. Liu C, Lou W, Zhu Y, Yang JC, Nadiminty N, Gaikwad N, Evans CP, Gao AC. Intracrine androgens and AKR1C3 activation confer resistance to enzalutamide in prostate cancer. Cancer Res. 2015; 75:1413-1422. [PubMed: 25649766]

36. Adeniji AO, Twenter BM, Byrns MC, Jin Y, Chen M, Winkler JD, Penning TM. Development of potent and selective inhibitors of aldo-keto reductase 1C3 (type 5 17 $\beta$-hydroxysteroid 
dehydrogenase) based on $N$-phenyl-aminobenzoates and their structure-activity relationships. J. Med. Chem. 2012; 55:2311-2323. [PubMed: 22263837]

37. Liedtke AJ, Adeniji AO, Chen M, Byrns MC, Jin Y, Christianson DW, Marnett LJ, Penning TM. Development of potent and selective indomethacin analogues for the inhibition of AKR1C3 (type 5 17 $\beta$-hydroxysteroid dehydrogenase/prostaglandin F synthase) in castrate-resistant prostate cancer. J. Med. Chem. 2013; 56:2429-2446. [PubMed: 23432095]

38. Rizner TL, Lin HK, Peehl DM, Steckelbroeck S, Bauman DR, Penning TM. Human type 3 3ahydroxysteroid dehydrogenase (aldo-keto reductase 1C2) and androgen metabolism in prostate cells. Endocrinology. 2003; 144:2922-2932. [PubMed: 12810547]

39. Steckelbroeck S, Jin Y, Gopishetty S, Oyesanmi B, Penning TM. Human cytosolic 3ahydroxysteroid dehydrogenases of the aldoketo reductase superfamily display significant $3 \beta$ hydroxysteroid dehydrogenase activity: implications for steroid hormone metabolism and action. J. Biol. Chem. 2004; 279:10784-10795. [PubMed: 14672942]

40. Penning TM, Bauman DR, Jin Y, Rizner TL. Identification of the molecular switch that regulates access of 5a-DHT to the androgen receptor. Mol. Cell. Endocrinol. 2007:265-266. 77-82.

41. Gu Y, Guise CP, Patel K, Abbattista MR, Lie J, Sun X, Atwell GJ, Boyd M, Patterson AV, Wilson WR. Reductive metabolism of the dinitrobenzamide mustard anticancer prodrug PR-104 in mice. Cancer Chemother. Pharmacol. 2011; 67:543-555. [PubMed: 20473609]

42. Duggan KC, Walters MJ, Musee J, Harp JM, Kiefer JR, Oates JA, Marnett LJ. Molecular basis for cyclooxygenase inhibition by the non-steroidal anti-inflammatory drug naproxen. J. Biol. Chem. 2010; 285:34950-34959. [PubMed: 20810665]

43. Duggan KC, Hermanson DJ, Musee J, Prusakiewicz JJ, Scheib JL, Carter BD, Banerjee S, Oates JA, Marnett LJ. ( $R$ )-Profens are substrate-selective inhibitors of endocannabinoid oxygenation by COX-2. Nat. Chem. Biol. 2011; 7:803-809. [PubMed: 22053353]

44. Byrns MC, Jin Y, Penning TM. Inhibitors of type 5 17 $\beta$-hydroxysteroid dehydrogenase (AKR1C3): overview and structural insights. J. Steroid Biochem. Mol. Biol. 2011; 125:95-104. [PubMed: 21087665]

45. Byrns MC, Penning TM. Type 5 17 $\beta$-hydroxysteroid dehydrogenase/prostaglandin F synthase (AKR1C3): role in breast cancer and inhibition by non-steroidal anti-inflammatory drug analogs. Chem.-Biol. Interact. 2009; 178:221-227. [PubMed: 19010312]

46. Adeniji AO, Chen M, Penning TM. AKR1C3 as a target in castrate resistant prostate cancer. J. Steroid Biochem. Mol. Biol. 2013; 137:136-149. [PubMed: 23748150]

47. Chen M, Adeniji AO, Twenter BM, Winkler JD, Christianson DW, Penning TM. Crystal structures of AKR1C3 containing an $N$-(aryl)amino-benzoate inhibitor and a bifunctional AKR1C3 inhibitor and androgen receptor antagonist. Bioorg. Med. Chem. Lett. 2012; 22:3492-3497. [PubMed: 22507964]

48. Flanagan JU, Yosaatmadja Y, Teague RM, Chai MZ, Turnbull AP, Squire CJ. Crystal structures of three classes of non-steroidal anti-inflammatory drugs in complex with aldo-keto reductase $1 \mathrm{C} 3$. PLoS One. 2012; 7:e43965. [PubMed: 22937138]

49. Gazvoda M, Beranic N, Turk S, Burja B, Kocevar M, Rizner TJ, Gobec S, Polanc S. 2,3Diarylpropenoic acids as selective non-steroidal inhibitors of type-5 17 $\beta$-hydroxysteroid dehydrogenase (AKR1C3). Eur. J. Med. Chem. 2013; 62:89-97. [PubMed: 23353746]

50. Heinrich DM, Flanagan JU, Jamieson SM, Silva S, Rigoreau LJ, Trivier E, Raynham T, Turnbull AP, Denny WA. Synthesis and structure-activity relationships for 1-(4-(piperidin-1ylsulfonyl)phenyl)pyrrolidin-2-ones as novel non-carboxylate inhibitors of the aldo-keto reductase enzyme AKR1C3. Eur. J. Med. Chem. 2013; 62:738-744. [PubMed: 23454516]

51. Kikuchi A, Furutani T, Azami H, Watanabe K, Niimi T, Kamiyama Y, Kuromitsu S, Baskin-Bey E, Heeringa M, Ouatas T, Enjo K. In vitro and in vivo characterization of ASP9521: a novel selective, orally bioavailable inhibitor of $17 \beta$-hydroxysteroid dehydrogenase type 5 (17 $\beta$-HSD5; AKR1C3). Invest. New Drugs. 2014; 32:860-870. [PubMed: 24981575]

52. Skarydova L, Hofman J, Chlebek J, Havrankova J, Kosanova K, Skarka A, Hostalkova A, Plucha T, Cahlikova L, Wsol V. Isoquinoline alkaloids as a novel type of AKR1C3 inhibitors. J. Steroid Biochem. Mol. Biol. 2014; 143:250-258. [PubMed: 24769118] 
53. Adeniji A, Twenter BM, Byrns MC, Jin Y, Winkler JD, Penning TM. Discovery of substituted 3(phenylamino)benzoic acids as potent and selective inhibitors of type $517 \beta$-hydroxysteroid dehydrogenase (AKR1C3). Bioorg. Med. Chem. Lett. 2011; 21:1464-1468. [PubMed: 21277203]

54. Harrison IT, Lewis B, Nelson P, Rooks W, Roszkowski A, Tomolonis A, Fried JH. Nonsteroidal antiinflammatory agents. I. 6-substituted 2-naphthylacetic acids. J. Med. Chem. 1970; 13:203-205. [PubMed: 5418489]

55. Bauman DR, Rudnick SI, Szewczuk LM, Jin Y, Gopishetty S, Penning TM. Development of nonsteroidal antiinflammatory drug analogs and steroid carboxylates selective for human aldo-keto reductase isoforms: potential antineoplastic agents that work independently of cyclooxygenase isozymes. Mol. Pharmacol. 2005; 67:60-68. [PubMed: 15475569]

56. Jackson VJ, Yosaatmadja Y, Flanagan JU, Squire CJ. Structure of AKR1C3 with 3phenoxybenzoic acid bound. Acta Crystallogr., Sect. F. Struct. Biol. Cryst. Commun. 2012; 68:409-413.

57. Lovering AL, Ride JP, Bunce CM, Desmond JC, Cummings SM, White SA. Crystal structures of prostaglandin $\mathrm{D}(2)$ 11-ketoreductase (AKR1C3) in complex with the nonsteroidal antiinflammatory drugs flufenamic acid and indomethacin. Cancer Res. 2004; 64:1802-1810. [PubMed: 14996743]

58. Gant, TG.; Sarshar, S.; Woo, H. Preparation and utility of substituted carboxylic acid compounds as COX-modulators. USA Patent. US20070276042A1. 2007. 20071129, 2007

59. Arewang CJ, Lahmann M, Oscarson S, Tiden A. Synthesis of urine drug metabolites: glucuronic and glycosides of phenol intermediates. Carbohydr. Res. 2007; 342:970-974. [PubMed: 17324385]

60. Kovacs I, Belanger-Gariepy F, Shaver A. Synthesis and characterization of mononuclear iron silanethiolato complexes containing an unsupported Fe-Si-Si bond system: X-ray structure of $\mathrm{CpFe}(\mathrm{CO}) 2 \mathrm{SSiPh}_{3}$ and its reaction with $\mathrm{SO}_{2}$. Inorg. Chem. 2003; 42:2988-2991. [PubMed: 12716192]

61. Burczynski ME, Harvey RG, Penning TM. Expression and characterization of four recombinant human dihydrodiol dehydrogenase isoforms: oxidation of trans-7, 8-dihydroxy-7,8dihydrobenzo[a]-pyrene to the activated $o$-quinone metabolite benzo[a]pyrene-7,8-dione. Biochemistry. 1998; 37:6781-6790. [PubMed: 9578563]

62. Smith T, Leipprandt J, DeWitt D. Purification and characterization of the human recombinant histidine-tagged prostaglandin endoperoxide H synthases-1 and -2. Arch. Biochem. Biophys. 2000; 375:195-200. [PubMed: 10683267]

63. Cherian MT, Wilson EM, Shapiro DJ. A competitive inhibitor that reduces recruitment of androgen receptor to androgen-responsive genes. J. Biol. Chem. 2012; 287:23368-23380. [PubMed: 22589544]

64. Byrns MC, Mindnich R, Duan L, Penning TM. Overexpression of aldo-keto reductase 1C3 (AKR1C3) in LNCaP cells diverts androgen metabolism towards testosterone resulting in resistance to the 5a-reductase inhibitor finasteride. J. Steroid Biochem. Mol. Biol. 2012; 130:715. [PubMed: 22265960]

65. Windsor MA, Hermanson DJ, Kingsley PJ, Xu S, Crews BC, Ho W, Keenan CM, Banerjee S, Sharkey KA, Marnett LJ. Substrate-selective inhibition of cyclooxygenase-2: development and evaluation of achiral profen probes. ACS Med. Chem. Lett. 2012; 3:759-763. [PubMed: 22984634] 


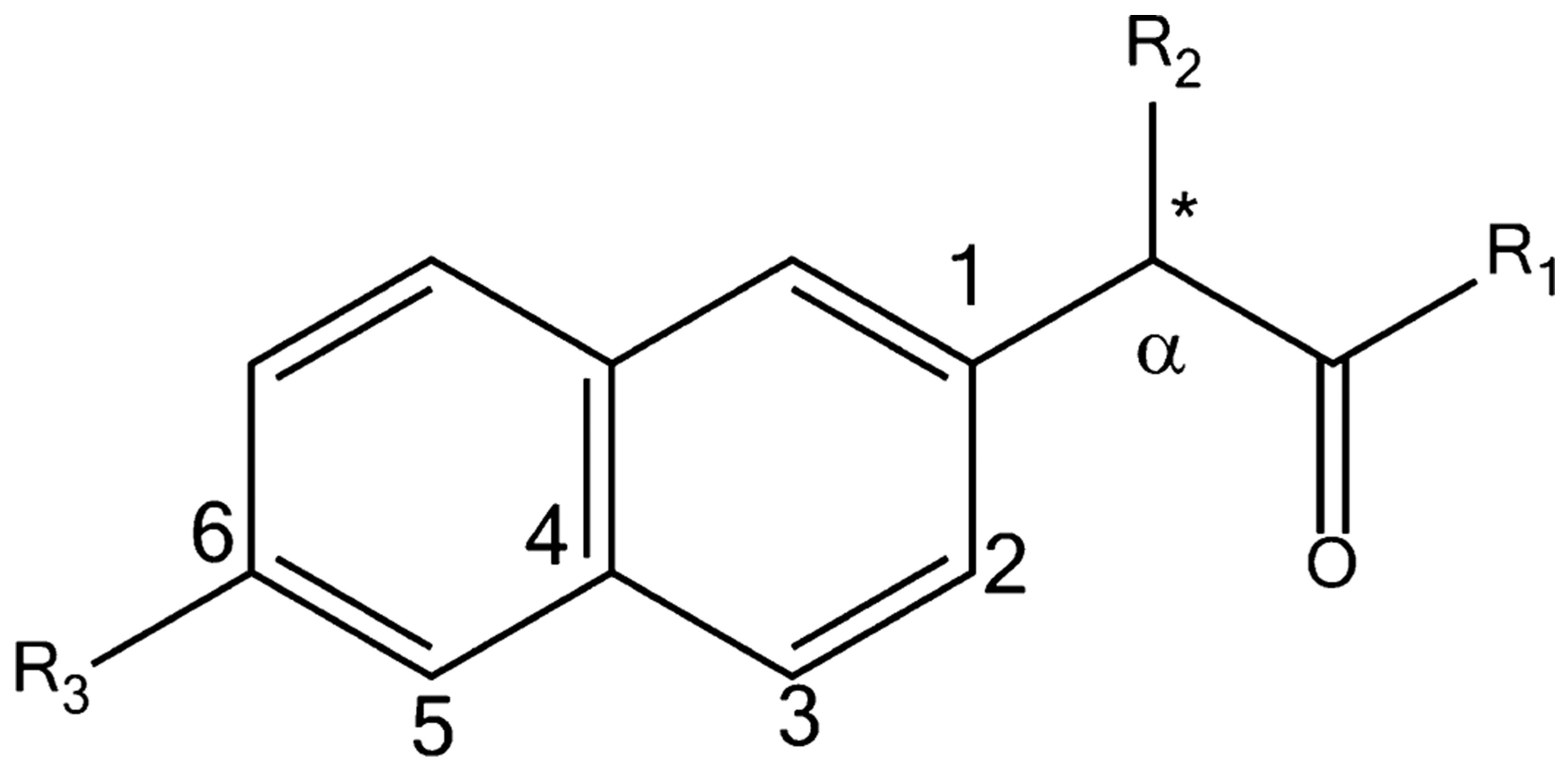

Figure 1.

Structure of naproxen analogues. 


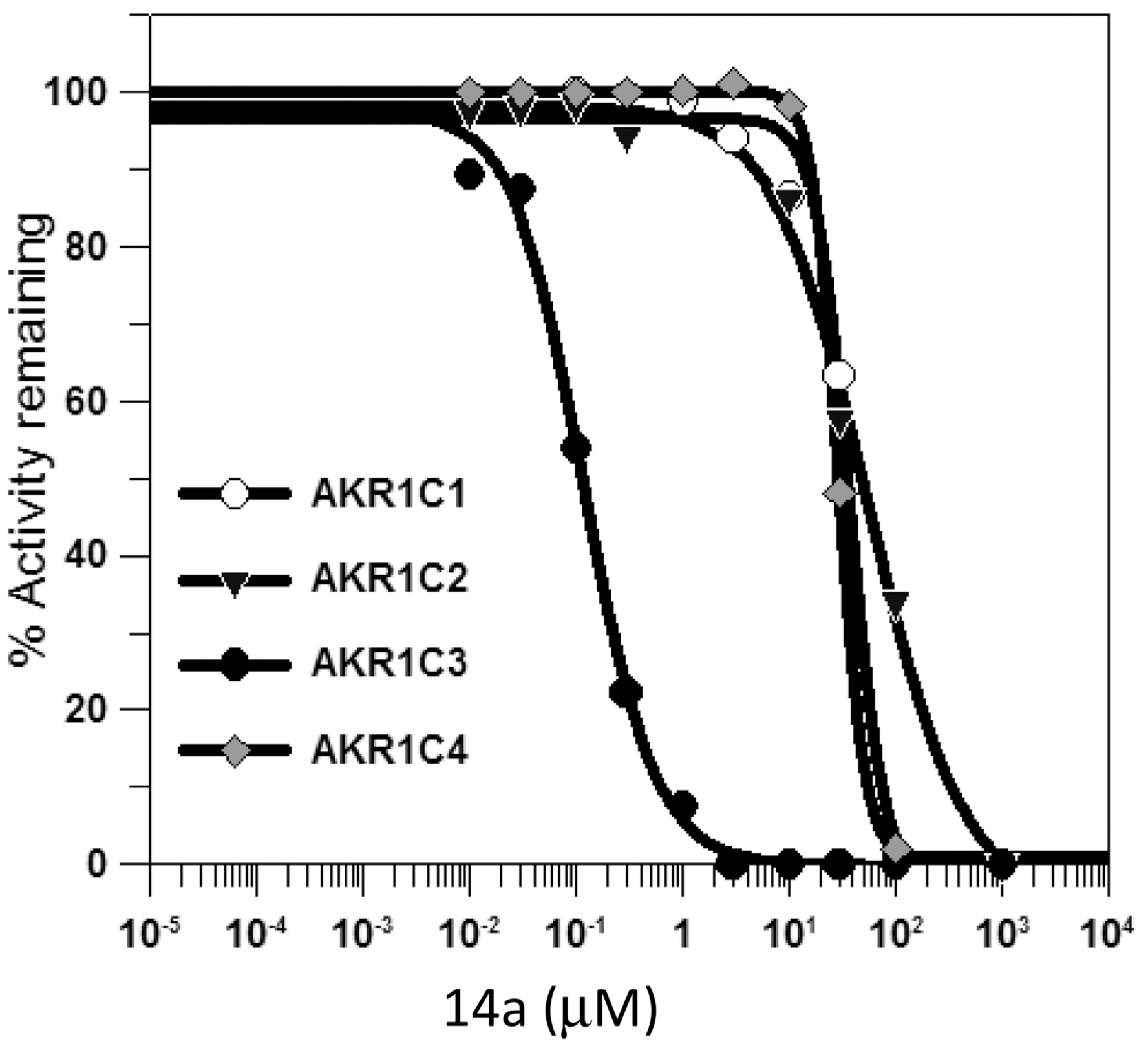

Figure 2.

Inhibitory effect of compound 14a on AKR1C1-4. 


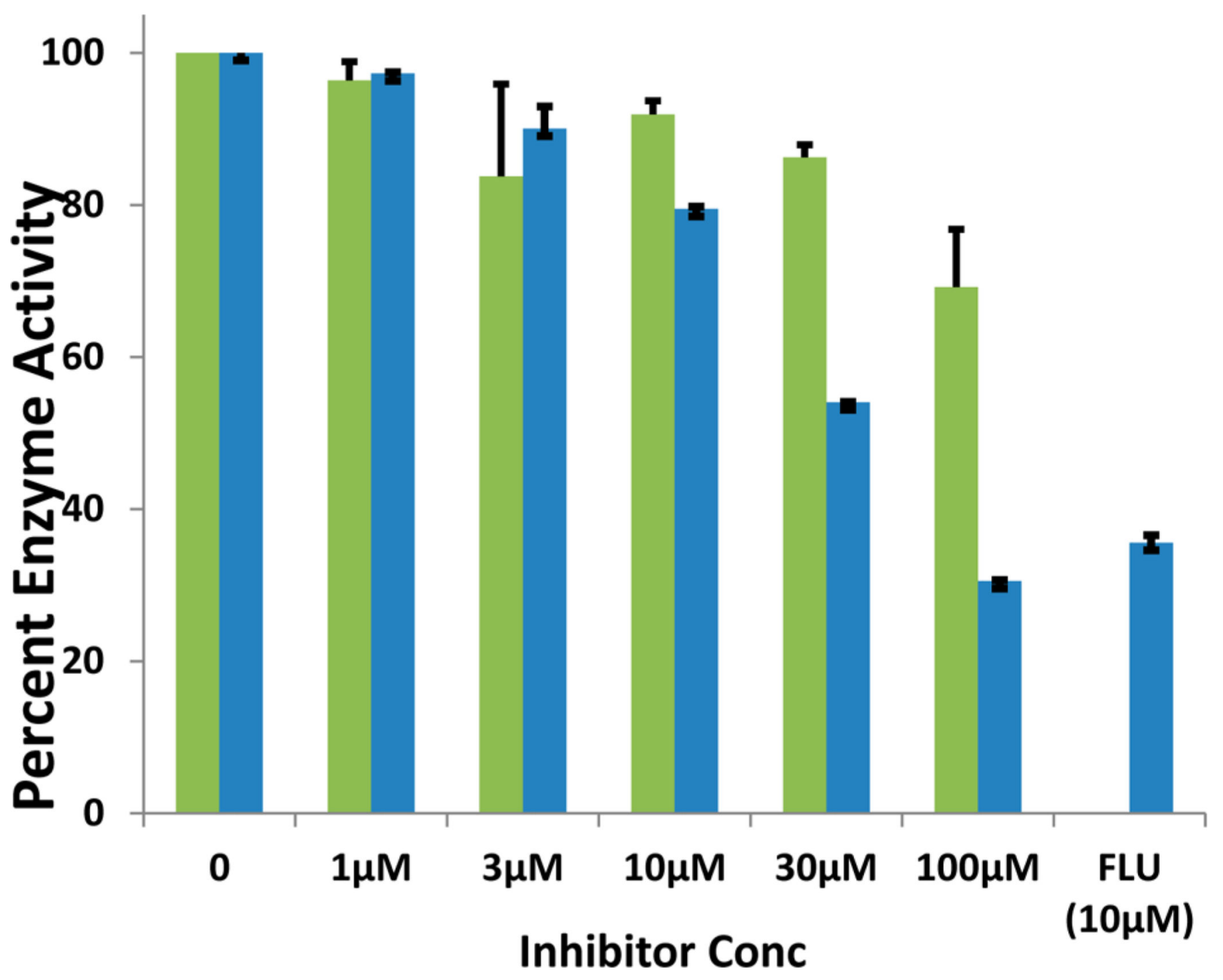

Figure 3.

Effect of compounds $14 \mathbf{a}$ (green) and $\mathbf{1 4 b}$ (blue) on AKR1C2 catalyzed reduction of 5aDHT. 
a

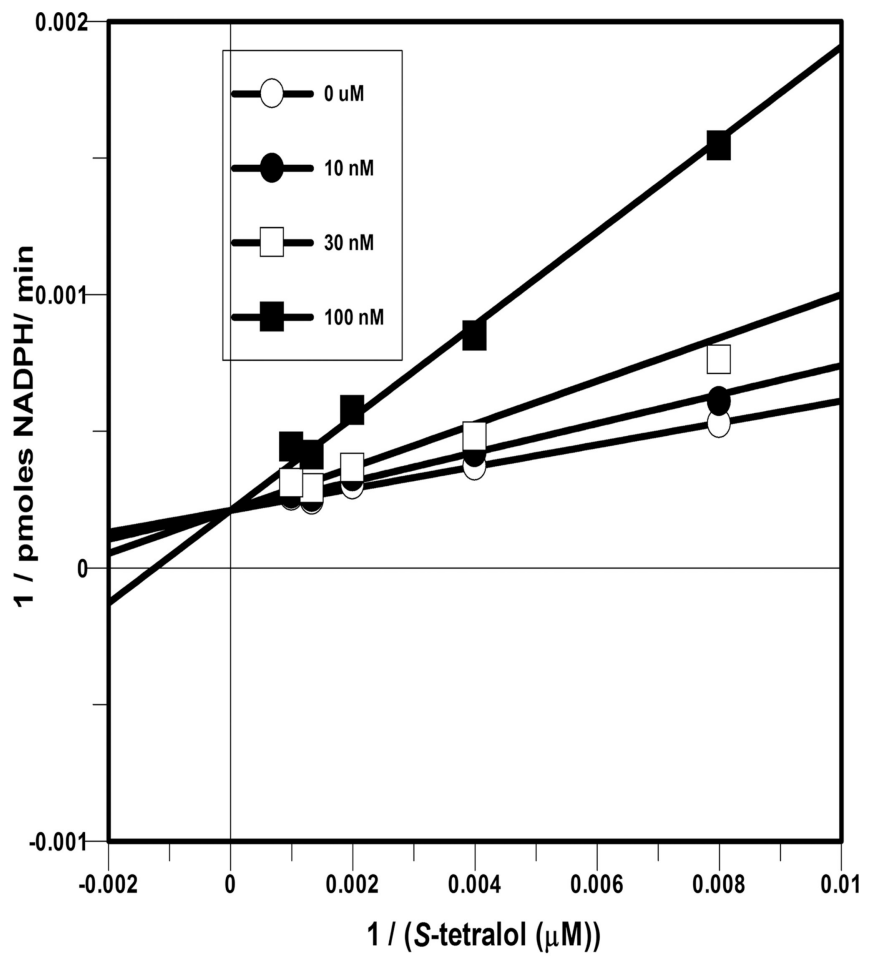

b

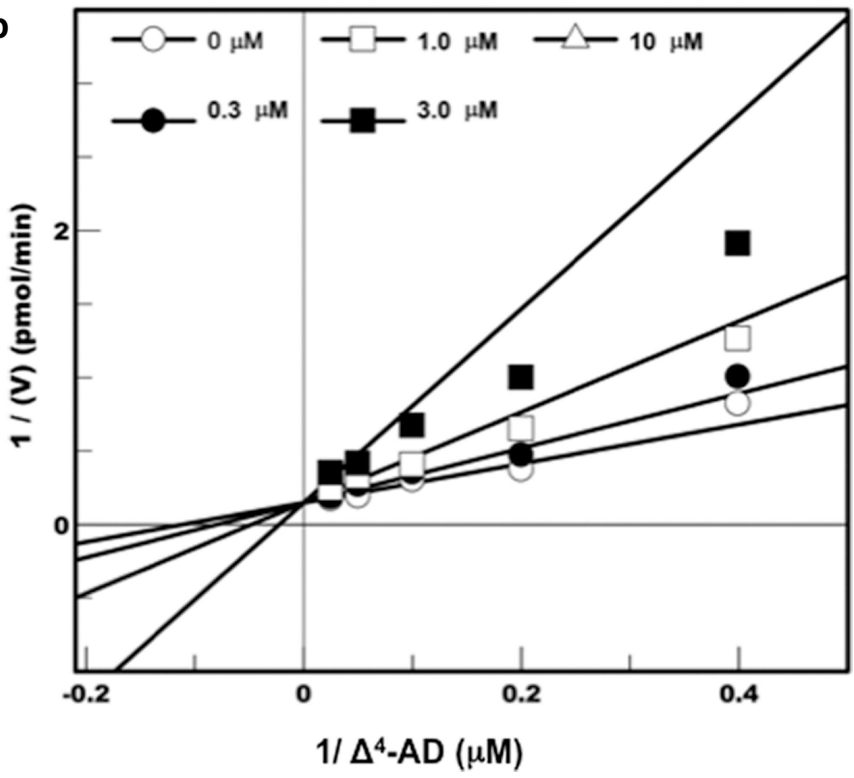

Figure 4.

(a) Competitive Inhibition of AKR1C3 catalyzed oxidation of $S$-tetralol by 14a. (b) Competitive Inhibition of AKR1C 3 catalyzed Reduction of $\Delta^{4}$-AD ( $\Delta^{4}$-androstene-3,17dione) by $\mathbf{1 4 a}$. 


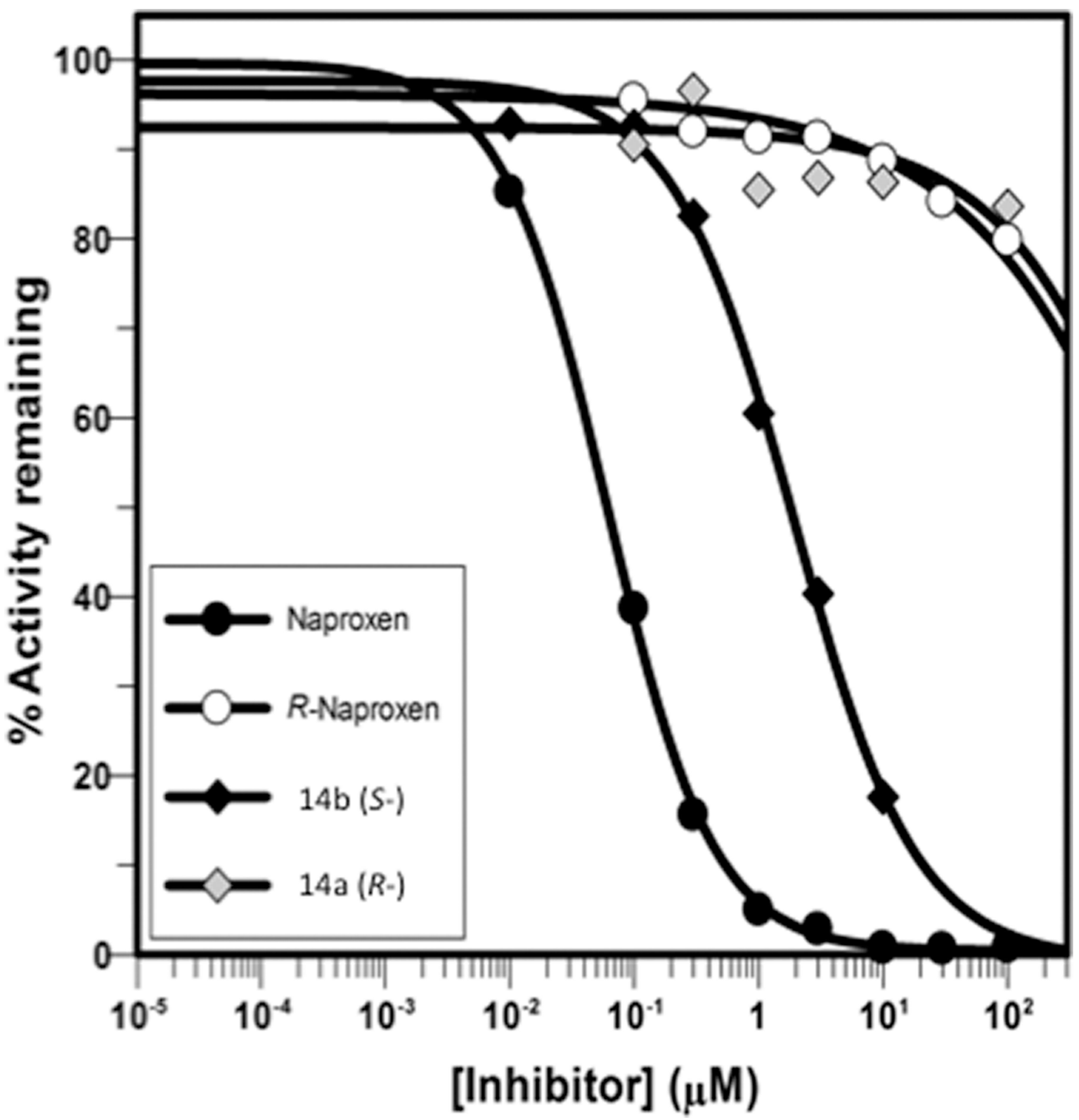

Figure 5.

Inhibition of COX-1 by naproxen analogues. 


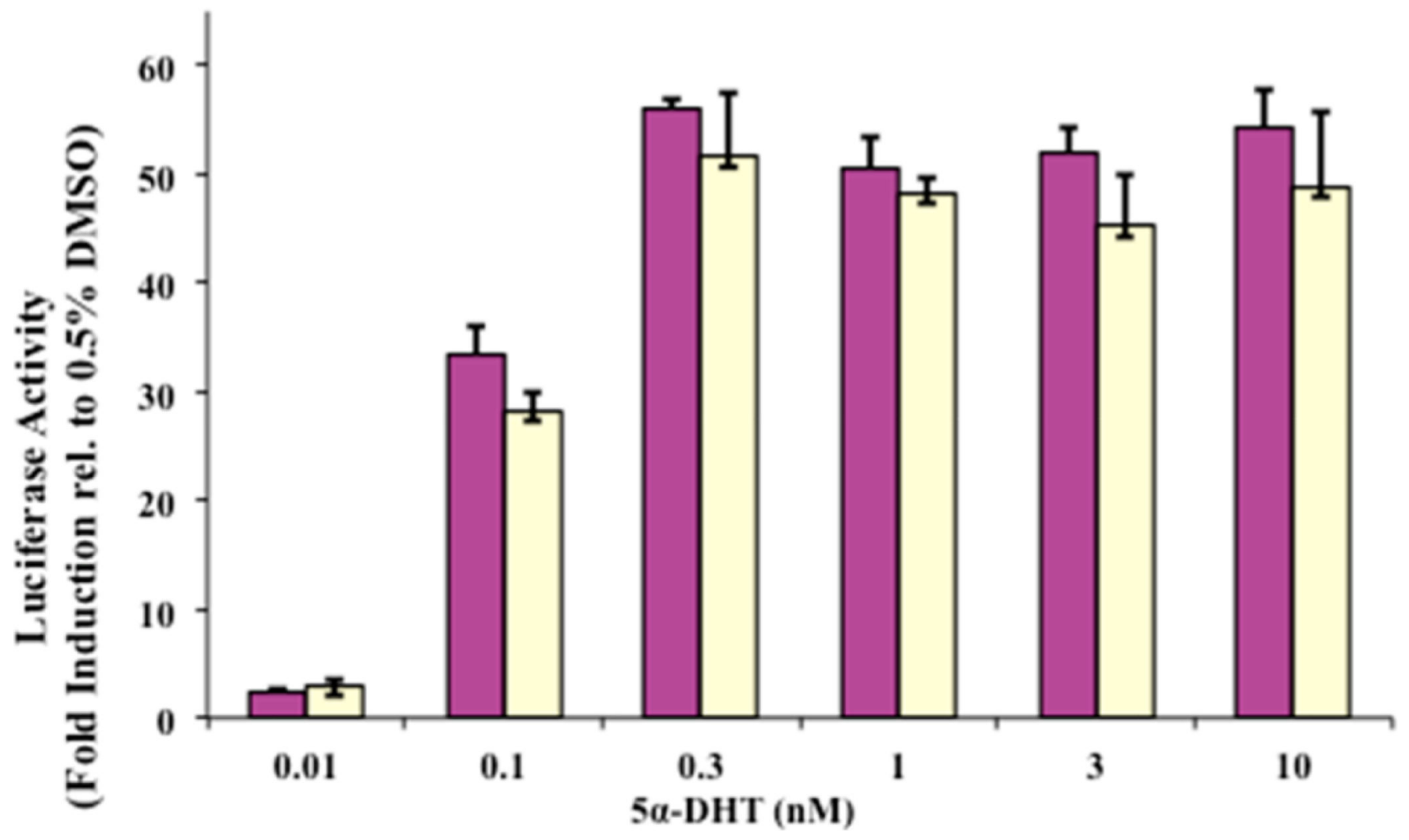

Figure 6.

Effect of compound 14a on DHT induced AR gene expression. DHT alone (purple) and DHT plus $10 \mu \mathrm{M}$ compound 14a. 
A. counts

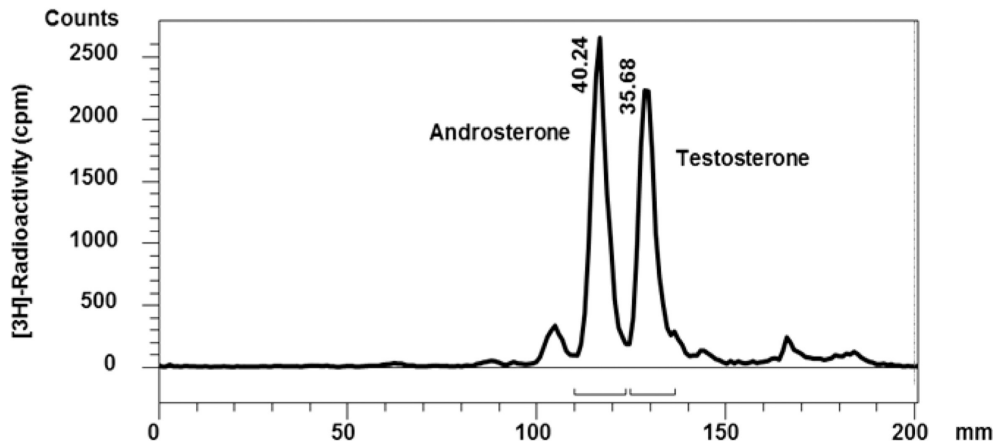

B. counts

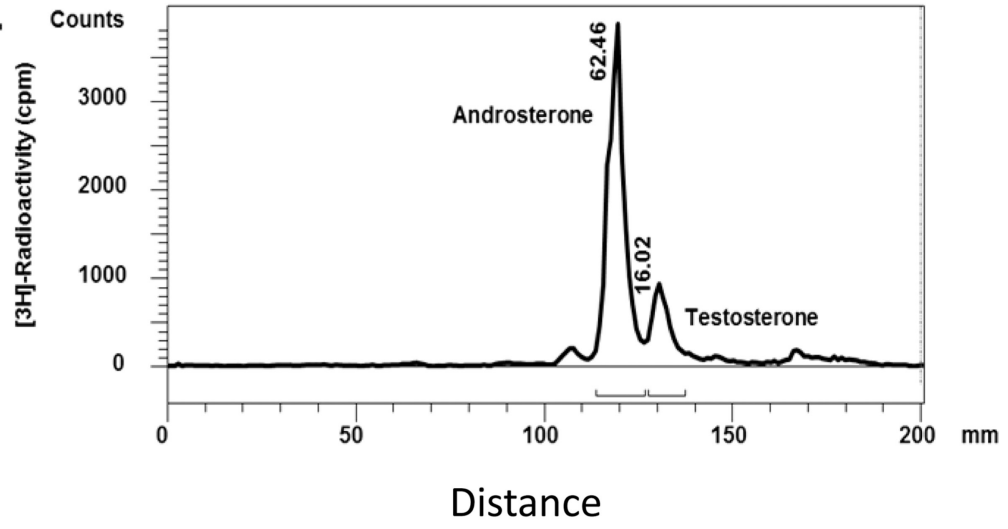

C

LNCaP-1C3 Testosterone Output
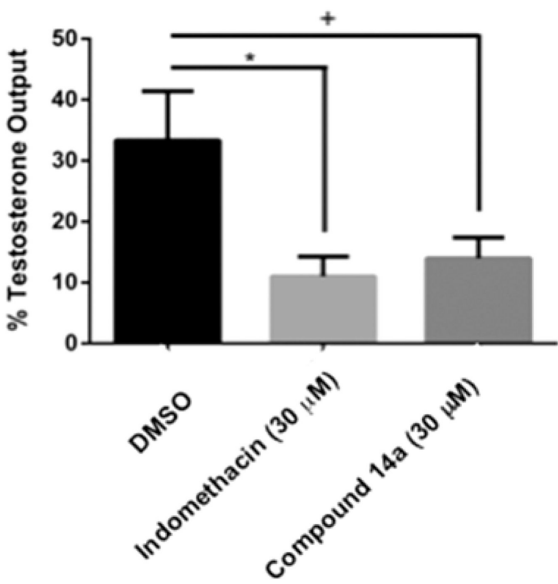

Figure 7.

Inhibition of testosterone formation in LNCaP-1C3 cells with compound 14a. (A) Conversion of $100 \mathrm{nM} \Delta^{4}$-AD to testosterone in LNCaP-AKR1C3 cells following digestion with $\beta$-glucurondiase. (B) Same experiment performed in the presence of $30 \mu \mathrm{M}$ compound 14a. (C) Statistical analysis of $n=3$ versus indomethacin as a positive control $* p$ value $<0.001 ; p$ value $=0.001$. 

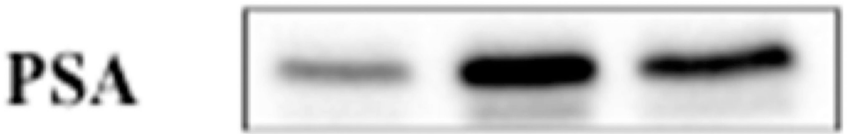

\section{$\beta$-tubulin}
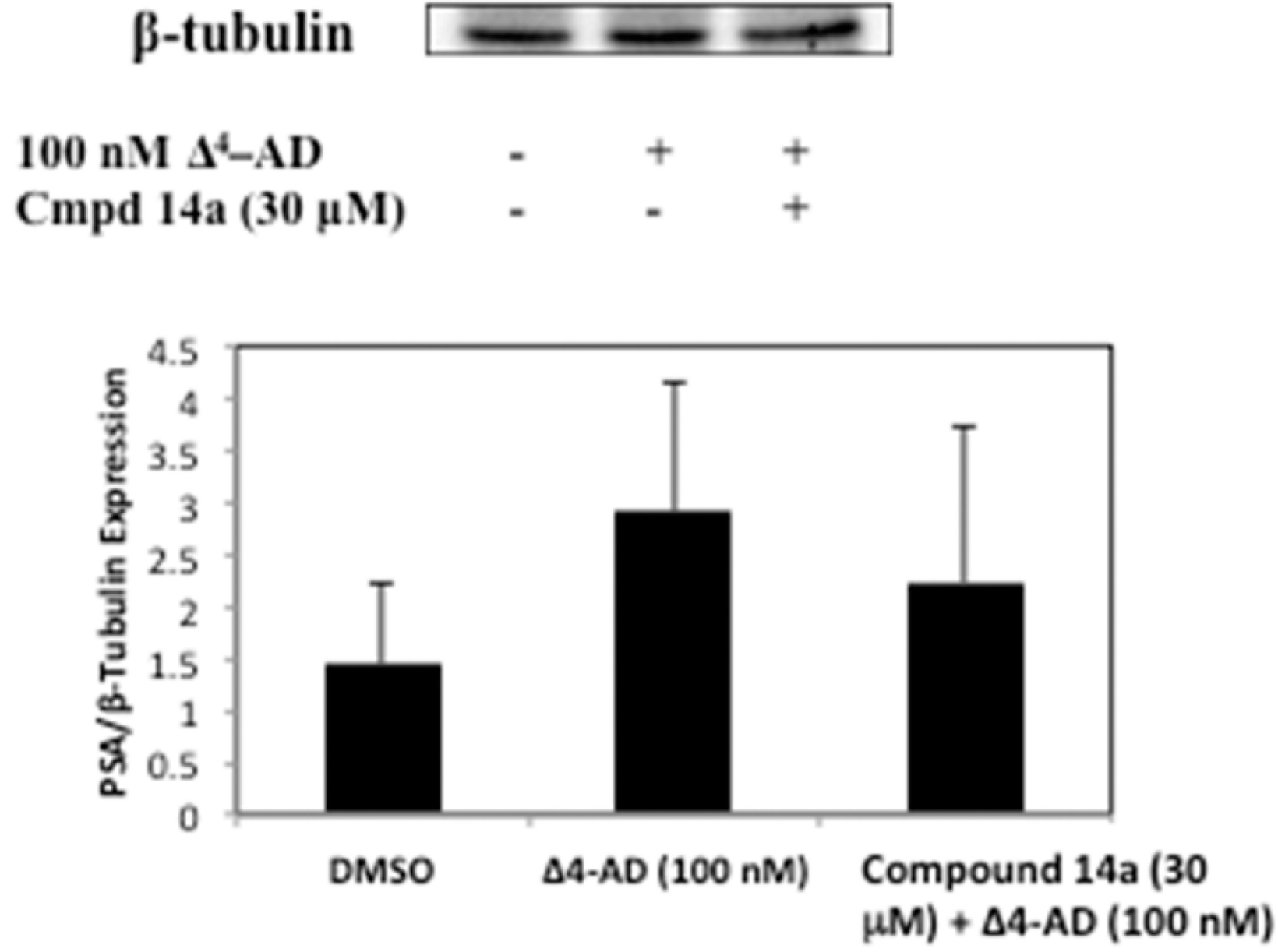

\section{Treatment}

Figure 8.

Inhibition of $\Delta^{4}-\mathrm{AD}$ induced PSA expression in LNCaP-AKR1C3 cells by compound $\mathbf{1 4 a}$. (A) Immunoblot. (B) Densitometric traces of immunoblots with normalization of PSA to $\beta$ tubulin for biological replicates $(n=3)$. 


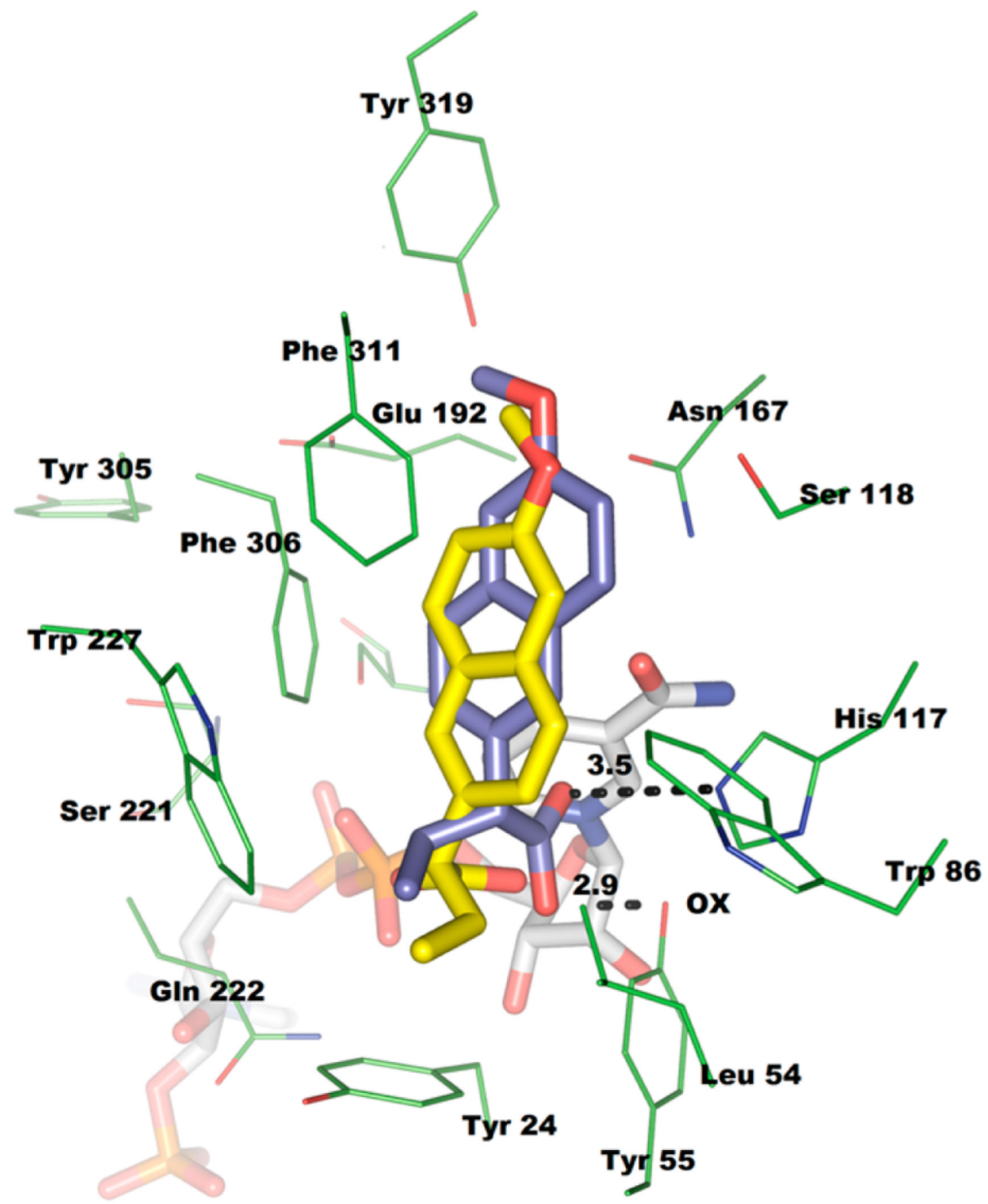

Figure 9.

Alignment of 14b and 14a in the AKR1C3 active site. AKR1C3 residues (green), 14b (yellow), 14a (purple), Dotted line: possible hydrogen bond. OX: oxyanion site (residues highlighted in pink). Ligand alignments were performed using LigAlign plugin in Pymol. The template crystal structures of the AKR1C3. NADP ${ }^{+}$complexes were chosen from the RCSB Protein Data Bank (PDB: 3UFY and 3R58) (also see Supporting Information). 


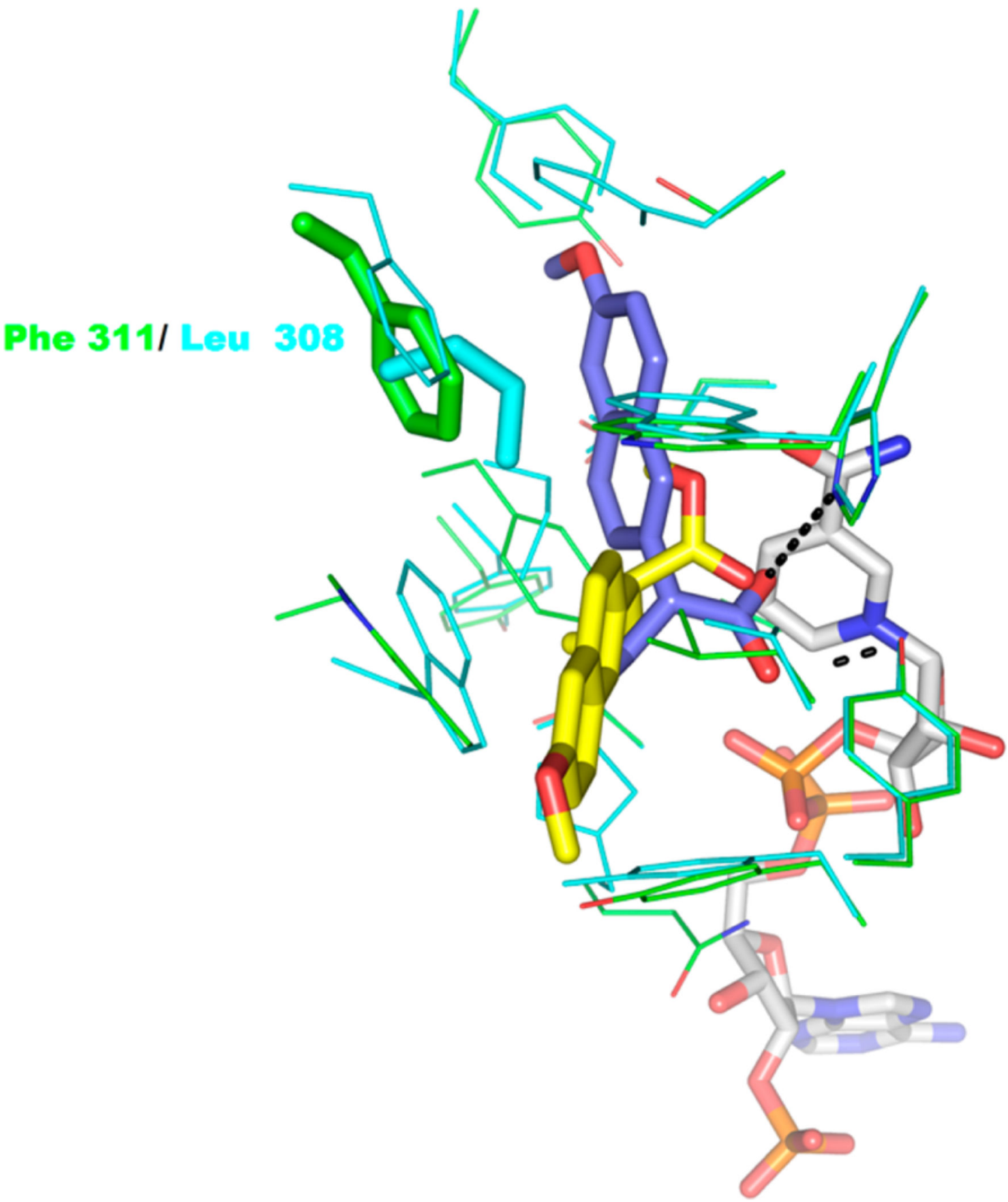

Figure 10.

Comparison of 14b and 14a binding to AKR1C2 and AKR1C3. 14b (yellow) and 14a (purple) binding modes in AKR1C2 (cyan) and AKR1C3 (green). Template crystal structure of the AKR1C2.NADP ${ }^{+}$complex was taken from the RCSB Protein Data Bank (PDB: 4JQ1) (also see Supporting Information). 


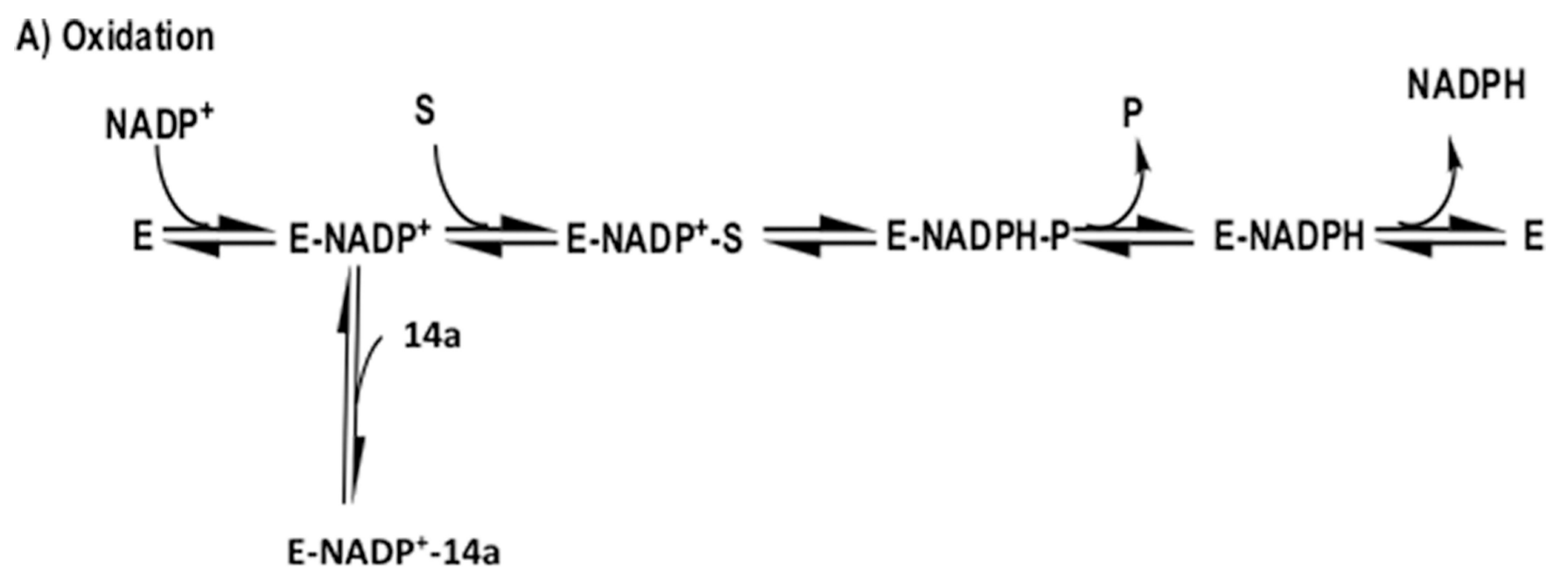

\section{B) Reduction}

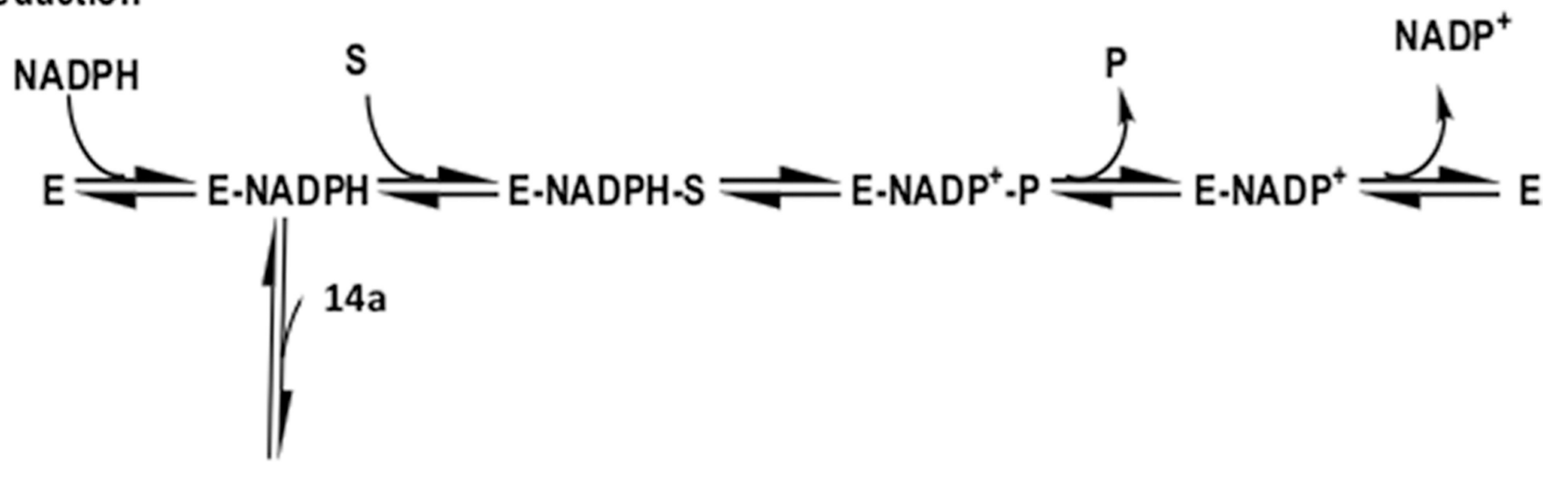

\section{E-NADPH-14a}

Figure 11.

Kinetic mechanism of the reactions catalyzed by AKR1C3. (A) Oxidation reaction where the substrate $\mathrm{S}$ is $S$-tetralol and the product $\mathrm{P}$ is tetralone, and (B) reduction reaction where the substrate is $\Delta^{4}$-androstene-3,17-dione and the product is testosterone. $\mathrm{S}=$ substrate, $\mathrm{P}=$ product, and $\mathrm{E}=$ enzyme. 
<smiles></smiles>

\begin{tabular}{|r|r|r|r|r|}
\hline AKR1C3 & AKR1C3 & AKR1C3 & AKR1C3 & \multicolumn{2}{|c|}{ Androsteron } \\
\hline \hline
\end{tabular}

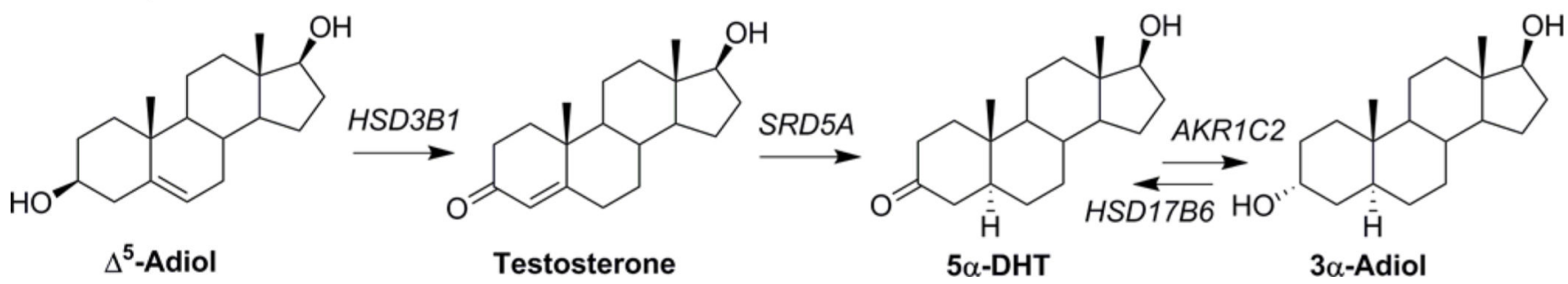

Scheme 1. Central Role of AKR1C3 in Androgen Biosynthesis in Prostate Cancera

${ }^{a}$ DHEA $=$ dehydroepiandrosterone, $\Delta^{4}-\mathrm{AD}=\Delta^{4}$-androstene-3,17-dione, Adione $=5 \mathrm{a}$ androstane-3,17-dione, $\Delta^{5}$-Adiol $=\Delta^{5}$-androstene- $3 \beta, 17 \beta$-diol, 5a-DHT $=5 a$ dihydrotestosterone. Enzymes are referred to by their gene names and are italicized: $H S D 3 B 1=3 \beta$-hydroxysteroid dehydrogenase type 1, SRD5A 5a-reductase type 1 or type 2, $A K R 1 C 2=$ type $33 a-$-hydroxysteroid dehydrogenase, and $H S D 17 B 6=17 \beta$-hydroxysteroid dehydrogenase type 6 . 
<smiles>COc1ccc2cc(C(I)C(=O)O)ccc2c1</smiles><smiles>O=C(O)C(I)c1ccc2cc(O)ccc2c1</smiles><smiles>C#CCOC(=O)C(I)c1ccc2cc(OS(C)(=O)=O)ccc2c1</smiles><smiles>COC(=O)C(I)c1ccc2cc(O)ccc2c1</smiles>

Scheme 2. Synthesis of Racemic Naproxen Analogues 2-6a

aReagents and conditions: (i) $48 \% \mathrm{HBr}$, AcOH, reflux, $3 \mathrm{~h}$; (ii) $\mathrm{TMSCl}, \mathrm{CH}_{3} \mathrm{OH}, 25{ }^{\circ} \mathrm{C}, 2 \mathrm{~h}$; (iii) $\left(\mathrm{CF}_{3} \mathrm{SO}_{2}\right)_{2} \mathrm{O}, \mathrm{Et}_{3} \mathrm{~N}, \mathrm{DCM}, 2{ }^{\circ} \mathrm{C}, 1 \mathrm{~h}$; (iv) $\mathrm{CH}_{2}=\mathrm{CHBF}_{3} \mathrm{~K}, \mathrm{Cs}_{2} \mathrm{CO}_{3}, \mathrm{Pd}\left(\mathrm{PPh}_{3}\right)_{4}, \mathrm{Et}_{3} \mathrm{~N}$, $\mathrm{EtOH}, 50{ }^{\circ} \mathrm{C}, 16 \mathrm{~h}$; (v) $(\mathrm{OAc})_{2} \mathrm{Pd}, t-\mathrm{But}_{3} \mathrm{P}, \mathrm{HCO}_{2} \mathrm{H}, 25^{\circ} \mathrm{C}, 12 \mathrm{~h}$; (vi) $3 \mathrm{M} \mathrm{KOH} / \mathrm{CH}_{3} \mathrm{OH}$, reflux, $3 \mathrm{~h}$; (vii) $\mathrm{KOH} / \mathrm{C}_{2} \mathrm{H}_{5} \mathrm{I}, 25{ }^{\circ} \mathrm{C}, 30 \mathrm{~min}$; (viii) $3 \mathrm{M} \mathrm{KOH} / \mathrm{CH}_{3} \mathrm{OH}$, reflux, $2 \mathrm{~h}$. 
<smiles>COC(=O)C(I)c1ccc2cc(OS(=O)(=O)C(F)(F)F)ccc2c1</smiles><smiles>COC(=O)C(C)c1ccc2cc(S[Si](C(C)C)(C(C)C)C(C)C)ccc2c1</smiles><smiles>CSc1ccc2cc(C(I)C(=O)O)ccc2c1</smiles><smiles>COC(=O)C(I)c1ccc2cc(SC)ccc2c1</smiles>

B<smiles>COc1ccc2cc(Br)ccc2c1</smiles>

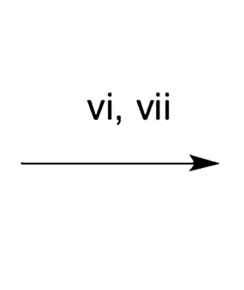<smiles>CS(=O)(=O)c1ccc2cc(C(I)C(=O)O)ccc2c1</smiles><smiles>CC[C@@H](C(=O)NS(C)(=O)=O)c1ccc2cc(OC)ccc2c1</smiles><smiles>[X]C</smiles><smiles>CC[C@H](C(=O)OC)c1ccc2cc(OC)ccc2c1</smiles>

Scheme 3. Synthesis of Racemic Naproxen Analogues 7-11 and 13-15a

${ }^{a}$ Reagents and conditions: (i) $\mathrm{Pd}\left(\mathrm{PPh}_{3}\right)_{4},\left[\left(\mathrm{CH}_{3}\right)_{2} \mathrm{CH}\right]_{3} \mathrm{SiSH}, \mathrm{C}_{6} \mathrm{H}_{6}$, reflux, $4 \mathrm{~h}$; (ii) TBAF, $\mathrm{CH}_{3} \mathrm{I}, 25^{\circ} \mathrm{C}, 2 \mathrm{~h}$; (iii) $3 \mathrm{M} \mathrm{KOH} / \mathrm{CH}_{3} \mathrm{OH}$, reflux, $2 \mathrm{~h}$; (iv) mCPBA, DCM $0{ }^{\circ} \mathrm{C}, 1 \mathrm{~h}$; (v) $\mathrm{KHSO}_{5} \cdot 0.5 \mathrm{KHSO}_{4} \cdot 0.5 \mathrm{~K}_{2} \mathrm{SO}_{4},\left(\mathrm{CH}_{3}\right)_{2} \mathrm{C}=\mathrm{O} / \mathrm{H}_{2} \mathrm{O} 25^{\circ} \mathrm{C}, 2 \mathrm{~h}$; (vi) $\mathrm{Mg}, \mathrm{I}_{2}$, THF, reflux, $1 \mathrm{~h}$; (vii) $\mathrm{CH}_{3} \mathrm{CH}_{2} \mathrm{CHBrCO}_{2} \mathrm{CH}_{3}$, THF, reflux, $2 \mathrm{~h}$; (viii) $3 \mathrm{M} \mathrm{KOH} / \mathrm{CH}_{3} \mathrm{OH}$, reflux, $2 \mathrm{~h}$, (ix) CDI, $\mathrm{CH}_{3} \mathrm{SO}_{2} \mathrm{NH}_{2}$, DBU, DCM, $25^{\circ} \mathrm{C}, 4 \mathrm{~h}$. 


\section{롤 \\ }

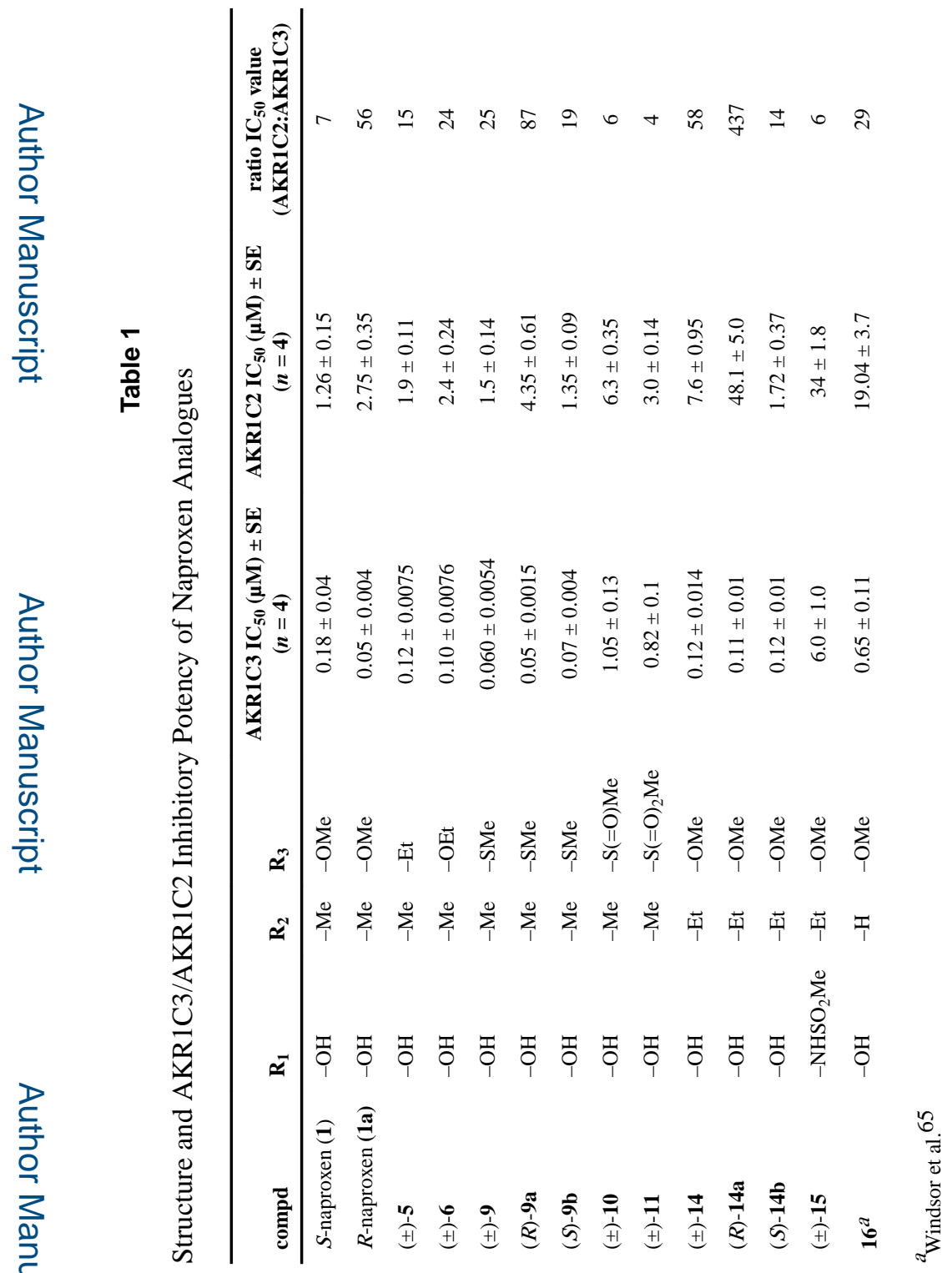




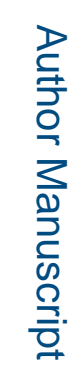

을

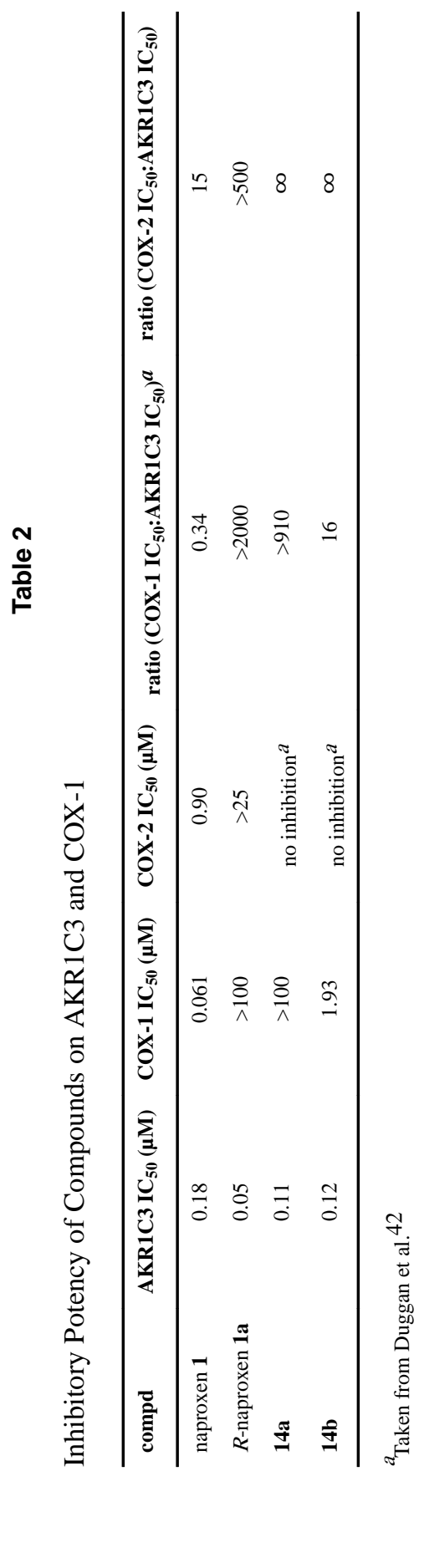

JMed Chem. Author manuscript; available in PMC 2017 August 25. 